\title{
Natural Products for the Treatment of Chlamydiaceae Infections
}

\author{
Mika A. Brown ${ }^{1,2,3,+}$, Michael G. Potroz ${ }^{1,2,+}$, Seoh-Wei Teh ${ }^{1,2}$ and Nam-Joon Cho ${ }^{1,2, *}$ \\ 1 School of Materials Science and Engineering, Nanyang Technological University, 50 Nanyang Avenue, \\ Singapore 639798, Singapore; mika.a.brown@gmail.com (M.A.B.); mikepotroz@gmail.com (M.G.P.); \\ seohwei1208@gmail.com (S.-W.T.) \\ 2 Centre for Biomimetic Sensor Science, 50 Nanyang Drive, Singapore 637553, Singapore \\ 3 Department of Chemical Engineering, Northeastern University, 360 Huntington Avenue, Boston, \\ MA 02115, USA \\ * Correspondence: njcho@ntu.edu.sg; Tel.: +65-6790-4925; Fax: +65-6790-9081 \\ + These authors contributed equally to this work.
}

Academic Editor: Eberhard Straube

Received: 18 July 2016; Accepted: 7 October 2016; Published: 16 October 2016

\begin{abstract}
Due to the global prevalence of Chlamydiae, exploring studies of diverse antichlamydial compounds is important in the development of effective treatment strategies and global infectious disease management. Chlamydiaceae is the most widely known bacterial family of the Chlamydiae order. Among the species in the family Chlamydiaceae, Chlamydia trachomatis and Chlamydia pneumoniae cause common human diseases, while Chlamydia abortus, Chlamydia psittaci, and Chlamydia suis represent zoonotic threats or are endemic in human food sources. Although chlamydial infections are currently manageable in human populations, chlamydial infections in livestock are endemic and there is significant difficulty achieving effective treatment. To combat the spread of Chlamydiaceae in humans and other hosts, improved methods for treatment and prevention of infection are needed. There exist various studies exploring the potential of natural products for developing new antichlamydial treatment modalities. Polyphenolic compounds can inhibit chlamydial growth by membrane disruption, reestablishment of host cell apoptosis, or improving host immune system detection. Fatty acids, monoglycerides, and lipids can disrupt the cell membranes of infective chlamydial elementary bodies (EBs). Peptides can disrupt the cell membranes of chlamydial EBs, and transferrins can inhibit chlamydial EBs from attachment to and permeation through the membranes of host cells. Cellular metabolites and probiotic bacteria can inhibit chlamydial infection by modulating host immune responses and directly inhibiting chlamydial growth. Finally, early stage clinical trials indicate that polyherbal formulations can be effective in treating chlamydial infections. Herein, we review an important body of literature in the field of antichlamydial research.
\end{abstract}

Keywords: Chlamydiae; Chlamydiaceae; Chlamydia; chlamydial infections; natural products; antibacterial

\section{Introduction}

Effective management of infectious diseases is one of most important endeavors of modern times. Infectious diseases impact human, animal, and environmental health, and beyond the direct cost of human disease management they influence the productivity of a wide range of agricultural practices. Chlamydiae are obligate intracellular bacteria that are known to be responsible for a wide range of serious global health-care challenges. From the Chlamydiaceae family within the Chlamydiae order, Chlamydia trachomatis and Chlamydia pneumoniae cause common human diseases, while Chlamydia abortus, Chlamydia psittaci, and Chlamydia suis represent zoonotic threats or are endemic in human food sources [1]. C. trachomatis is the leading cause of trachoma, which can lead to blindness 
if left untreated [2]. The same organism is also the most prevalent cause of sexually transmitted diseases worldwide [3]. C. pneumoniae has a 60\%-70\% seroprevalence in adults in western countries, and is associated with respiratory disease, pulmonary disease, atherosclerosis, and Alzheimer's disease [4]. The majority of our knowledge and research efforts from the past 50 years has focused on Chlamydiaceae as the most widely known bacterial family of the Chlamydiae order. However, in the past 20 years there has been the addition of eight families of genetically related obligate intracellular bacteria. These new families are often collectively referred to as "Chlamydia-like organisms" (CLOs), "Chlamydia-related bacteria" or "environmental Chlamydiae" [1]. The identification of such a diverse range of new Chlamydiae has promoted renewed interest in understanding chlamydial bacteria and chlamydial disease management.

More reliable methods to identify chlamydial infections are highlighting that they may be far more prevalent and significant than previously identified [5,6]. Although chlamydial infections within the human population are currently manageable with existing conventional therapies [7,8], chlamydial infections within livestock are of significant concern [6,9]. Chlamydial infections are endemic in the livestock industry, and it has been shown that antibiotics typically only manage the severity of infection rather than achieve clearance on a herd level [9]. Reports of tetracycline-resistant C. suis in swine herds continue, and chlamydial persistence and/or reinfection are the norm in many herd settings [10]. Both symptomatic and asymptomatic persistence, in animals and humans, is a serious problem. It has been proposed that increasing treatment durations for chlamydial infections may resolve persistent infections [11], and prophylactic treatment for a wide range of pathogenic microorganisms is common in livestock management [12]. However, extended exposure of Chlamydia to antibiotics provides greater opportunity for the development of antibiotic resistance in chlamydial species as well as other pathogenic microorganisms [10]. Therefore, the practice of extended treatment durations to prevent, manage, or resolve chlamydial infections should be used with caution, particularly with regards to livestock at a herd level.

Many common chlamydial strains have shown the potential to develop varying degrees of resistance to standard antibiotics in in vitro settings [13]. However, based on recent follow-up studies of the community-wide treatment of common human chlamydial pathogens, it seems that the development of resistance to front-line antibiotics is unlikely [14,15]. Of greatest concern is the largely underestimated zoonotic potential of livestock chlamydial pathogens [9]. If poor livestock management practices continue, such as generalized prophylactic antibiotic regimes, we may eventually see the appearance and introduction of resistant chlamydial strains into human circulation [10]. Vaccines provide an attractive option for chlamydial management, however, there currently exists commerically available vaccines for only two chlamydial species: C. abortus in sheep and goats and C. felis in cats [9]. Although there is significant progress in the devlopment of various chlamydial vaccines, the complex biphasic chlamydial lifecycle and tendency for asymptomatic persistent infections provide significant challenges [16]. At this time, to better manage chlamydial infections in both humans and animals, it is important to continue the search for new antichlamydial compounds.

The aim of this review is to summarize the research exploring natural products as leads to developing novel antibacterial compounds for various Chlamydiaceae species, as the most widely studied family of the Chlamydiae order. An overview of Chlamydiaceae infections and treatment is provided, followed by a review of various biomedical phytochemical groups and their associated anti-infective action. Polyphenolic compounds are discussed, followed by lipidic compounds, proteinaceous compounds, cellular metabolites and probiotics, and several examples of polyherbal formulations which have shown to exhibit significant antichlamydial activity.

\section{Overview of Chlamydiaceae}

Chlamydiales is an order of bacteria and related prokaryotic organisms consisting of nine families. All species within the order can be identified by analysis of their 16S rRNA. The most widely known 
of these families is Chlamydiaceae. While some of these bacterial species are host-specific, others like C. psittaci and C. abortus represent a potential zoonotic threat [1].

\subsection{Brief History}

In 1879, seven people in Switzerland were infected with C. psittaci by their imported tropical pet birds. This was the first discovery of C. psittaci as the cause of Psittacosis, or Parrot Fever. C. trachomatis was first discovered in 1907. However, both species were thought to be viruses until the first examination of the bacteria by microscopy in the 1960s. At the time, C. psittaci was thought to be part of the same genera as C. trachomatis and was named C. psittaci, while the strains found in animals were not known to be different species [17]. In 1985, Saikku et al., observed a connection between an unusual strain of C. psittaci and an epidemic of mild pneumonia in northern Finland [18]. This observation led to the identification of a new group of chlamydial organisms, which was termed TWAR in 1986 [19]. In 1988 and 1989, DNA-DNA hybridization studies of TWAR by Cox et al. [20] and Grayston et al. [21] revealed that it was a distinct chlamydial species, which became C. pneumoniae [22]. Work by Fukushi and Hirai in 1989 [23] led to the proposed existence of Chlamydia pecorum in 1992 [24]. In 1999, analysis of the $16 \mathrm{~S}$ and $23 \mathrm{~S}$ rRNA of Chlamydiaceae by Everett et al. indicated that there were two monophyletic lineages and nine species [25]. This was confirmed by other studies of 16S rRNA, the major outer membrane protein (MOMP), and ribosomal and coding genes. The other species of Chlamydiaceae were also discovered to be different species and named [26]. In 2000, Chlamydiaceae was defined as a family divided into two genera, Chlamydia and Chlamydophila [27], and comprised of nine species. However, in recent years, it has been proposed to shift back to a unification of the genera Chlamydia and Chlamydophila into a single genus [28]. In line with the majority of recent publications in the field, we are using the single genus "Chlamydia" in this paper. In 2014, two new species were identified [28], Chlamydia avium and Chlamydia gallinacea, and recent sources indicate that there are 11 Chlamydia species [1,29]. Although, research continues in this field and a 2015 review covering the past twenty years of research into chlamydia-like organisms identifies 15 Chlamydia species in the Chlamydiaceae family (Figure 1) [1].

\subsection{Chlamydiaceae Infections and Treatment}

All Chlamydiaceae exhibit the same biphasic development cycle (Figure 2) where elementary bodies (EBs) enter host cells and transform into metabolically active reticulate bodies (RBs). Elementary bodies (EBs) traveling through extracellular secretions inside a host attach to a eukaryotic host cell and are taken in through phagocytosis. The EBs reorganize to form reticulate bodies (RBs), the replicating form of Chlamydiaceae. Reticulate bodies inhibit the formation of phagolysosomes and utilize host cell metabolic intermediates to counteract natural defenses. Inside an inclusion, or membrane-bound vacuole in host cytoplasm, RBs divide by asynchronous binary fission. After 30-48 h, the new RBs condense to form new EBs. The host cell then lyses, releasing the elementary bodies [29].

Although all Chlamydiaceae share a biphasic life cycle, there are differences between chlamydial species in standard treatment, potential for antibiotic resistance, and overall infection characteristics. Even within chlamydial species there exist serovar and strain variations which have shown to be more or less resilient to treatment [11]. Additional treatment variations can be required dependent on host, as well as the acute or chronic nature of infection. Overall, there exists significant complexity in the range of potential treatment requirements for chlamydial infections. However, Table 1 provides a broad summary of standard antibiotics for treatment of typical hosts, whether any in vitro or in vivo antibiotic resistance has been reported, whether asymptomatic persistence is common, and what range of tissues may be infected. 


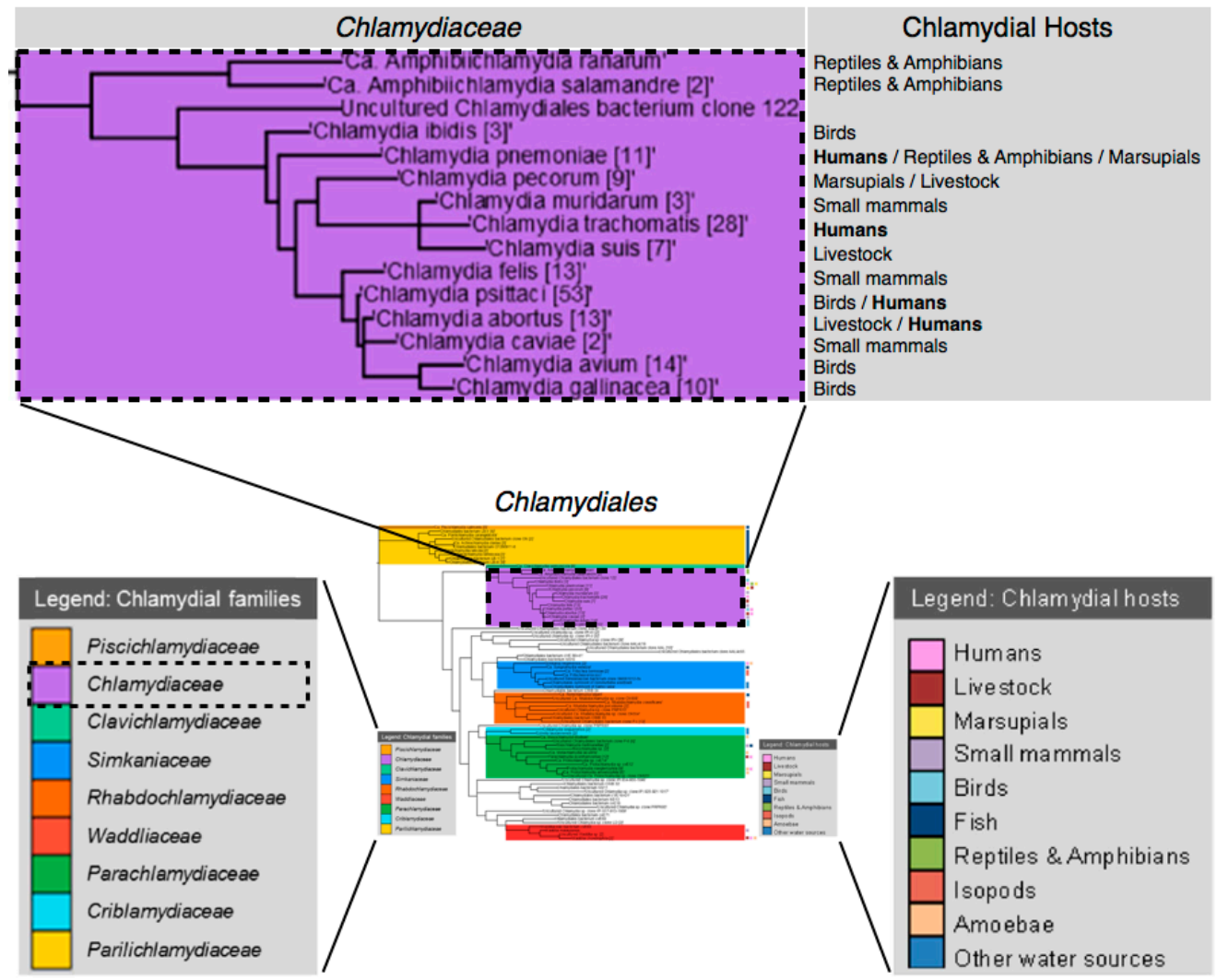

Figure 1. Chlamydiaceae species and hosts. From Chlamydiales phylogenetic tree with contents based on near full-length 16S rRNA gene sequences obtained from Genbank, NCBI. Adapted with permission from [1]. Copyright 2015 Oxford University Press. 


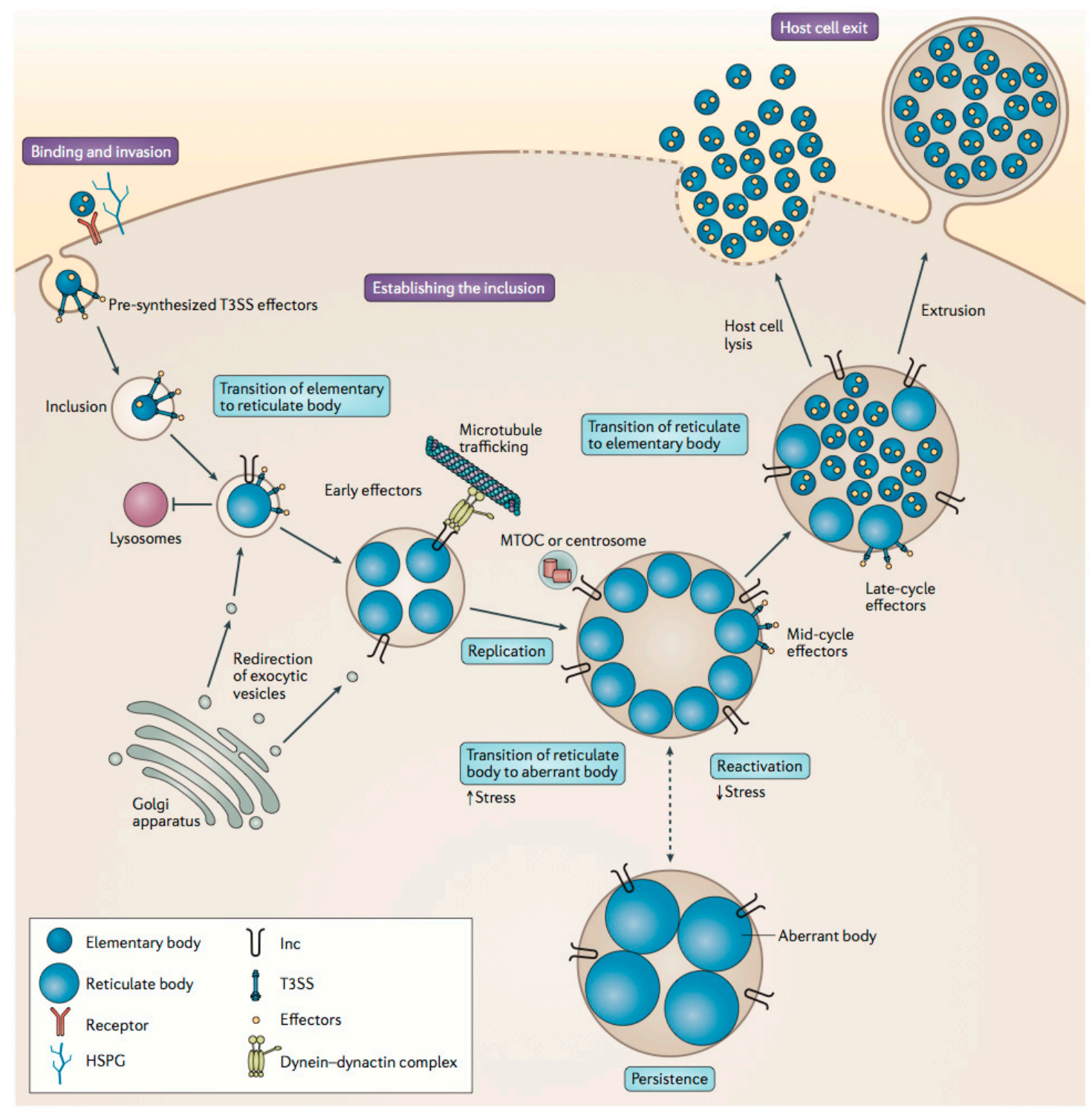

Figure 2. The life cycle of Chlamydia trachomatis. The elementary body (EB) binds to the host cell. Compounds are injected into the host cell to initiate internalization and establish an antiapoptotic state. The EB is incorporated into an endosomal membrane to form an inclusion, which is freed from the cell wall and passes into the host cell cytoplasm. Through bacterial protein synthesis the EB converts to reticulate bodies (RBs), which redirect host cell nutrients and divide by binary fission. The RBs direct host cell function and continue to replicate exponentially. If the RBs are excessively stressed they enter a dormant persistent state to promote survival, and reactivate upon removal of stress. Within $30-48 \mathrm{~h}$ the RBs differentiate back to EBs, which then exit the host cell through lysis or extrusion. Adapted with permission from [28]. Copyright 2016 Nature Publishing Group.

Frontline antibiotics for chlamydial infections include tetracyclines (TET) or macrolides (MAC), with doxycycline and azithromycin being the most common [5]. C. trachomatis within the human population remains manageable [7,8], although the potential for resistant forms has been reported [13]. Conversely, C. suis, which primarily infects swine, has shown to resist clearance at a herd level with a diverse range of antibiotics [12], and is the first of the Chlamydiaceae to develop stable TET-resistant forms in vivo [30]. C. psittaci responds well to TET or MAC treatment in humans and birds at an individual level [9,31], however, no reliable treatment is known for infections in cattle [6,32]. C. pneumoniae within the human population also remains manageable [5]. If detected and treated early, 
C. abortus in humans responds well to treatment with TET and erythromycin (MAC) [33], however, it is endemic in the livestock industry, and although oxytetracycline (TET) will reduce the number of abortions and bacterial shedding, antibiotics are ineffective in clearing the infection [9]. C pecorum is also endemic in the livestock industry [6], and in particular, no reliable treatment is known for infections in cattle [32], although, within Koala populations there has been some treatment success using chloramphenicol or enrofloxacin [34,35]. Other chlamydial species, such as C. muridarum, C. felis, and C. caviae, are generally manageable with TET and/or MAC treatment regimes [36-38]. C. avium and C. gallinacea have only recently been distinguished as distinct from C. psittaci, and for now it may be assumed that they have similar treatment and infection characteristics.

Table 1. Standard antibiotic treatments, potential resistance, and infection characteristics.

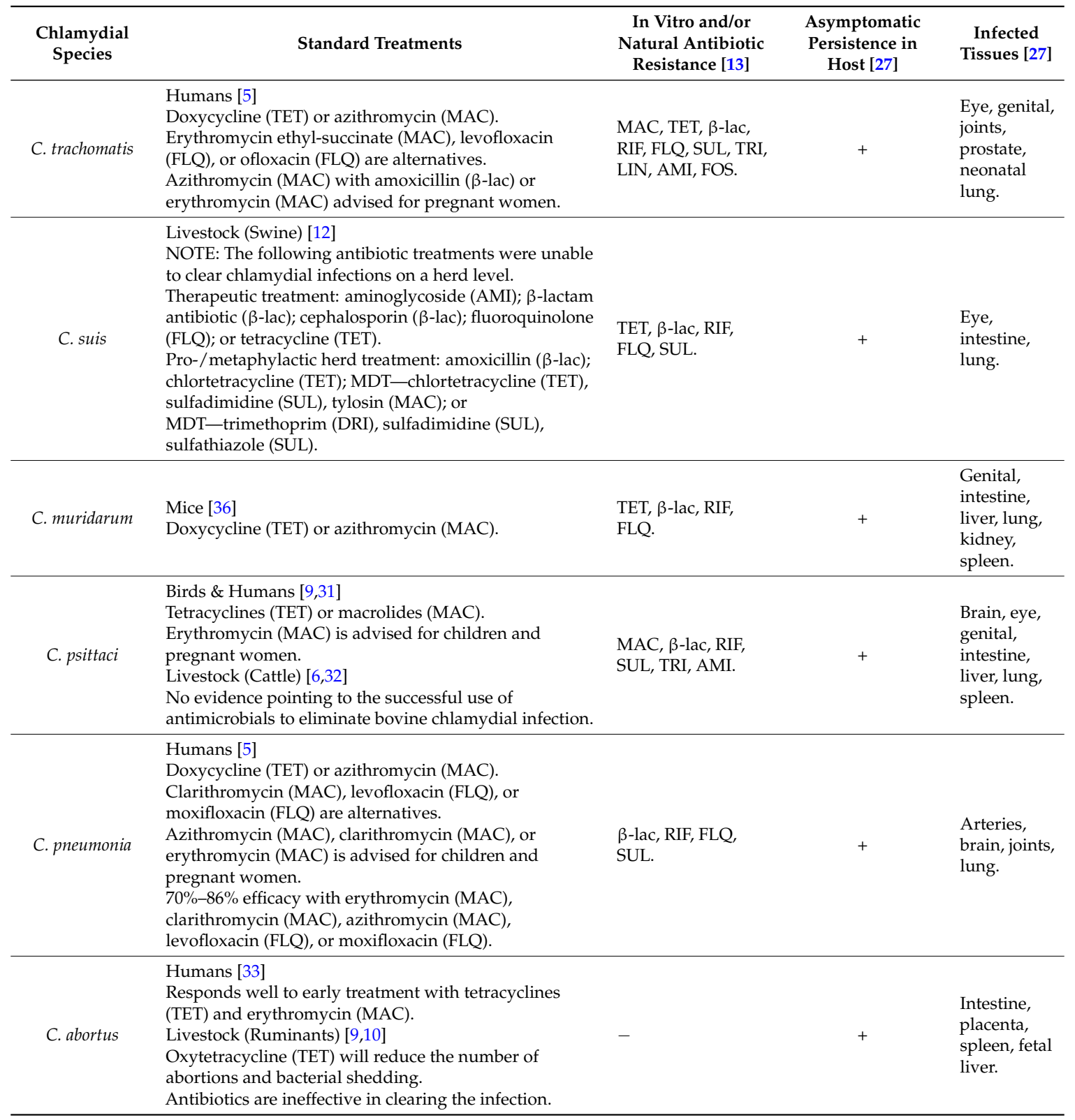


Table 1. Cont.

\begin{tabular}{|c|c|c|c|c|}
\hline $\begin{array}{l}\text { Chlamydial } \\
\text { Species }\end{array}$ & Standard Treatments & $\begin{array}{l}\text { In Vitro and/or } \\
\text { Natural Antibiotic } \\
\text { Resistance [13] }\end{array}$ & $\begin{array}{l}\text { Asymptomatic } \\
\text { Persistence in } \\
\text { Host [27] }\end{array}$ & $\begin{array}{c}\text { Infected } \\
\text { Tissues [27] }\end{array}$ \\
\hline C. felis & $\begin{array}{l}\text { Cats [37] } \\
\text { Doxycycline (TET) and topical tetracycline (TET). } \\
\text { MDT: Amoxicillin/clavulanic acid ( } \beta \text {-lac) may be a safe } \\
\text { alternative for kittens. }\end{array}$ & - & - & $\begin{array}{l}\text { Eye, genital, } \\
\text { joints, lung. }\end{array}$ \\
\hline C. avium & $\begin{array}{l}\text { Birds } \\
\text { Tetracyclines (TET) or macrolides (MAC)—based on } \\
\text { treatment for C. psittaci. }\end{array}$ & - & + & - \\
\hline C. gallinacea & $\begin{array}{l}\text { Birds } \\
\text { Tetracyclines (TET) or macrolides (MAC)—based on } \\
\text { treatment for C. psittaci. }\end{array}$ & - & + & - \\
\hline
\end{tabular}

Livestock infections from C. suis, C. psittaci, C. abortus, and C pecorum all exhibit significant difficulty to clear, especially at a herd level $[6,12,32]$. Treatment failure, persistence, and reinfection are all common in a range of animal hosts, with antibiotics typically providing only a reduction in infection severity for the duration of the treatment period $[6,10]$. It is proposed that livestock often exhibit infection by multiple chlamydial species at a time [12,32], and chlamydial species found in livestock are commonly present in the digestive tract (Table 1), which may complicate clearance and allow for reinfection [39]. Recent research points to asymptomatic chlamydial infections being responsible for huge reductions in livestock productivity and profits [6]. There is a strong need for new treatment options to avoid widespread prophylactic antibiotic treatment in the industry as a means to effectively manage potential financial losses.

\section{Biomedical Phytochemical Groups and Anti-Infective Action}

Approximately $80 \%$ of the world relies on plant-based medicine for treatment of all ailments and $70 \%$ of pharmaceutical therapeutics used today are models of natural products [40]. Herbal medicines may be useful as a starting point for the development of new antichlamydial drugs [41]. Natural products comprise a diverse range of biochemical compounds. Plant secondary metabolites comprise the largest group of compounds used in plant-based therapeutics with polyphenols being the most commonly studied secondary metabolite group with respect to the treatment of Chlamydiaceae infections. Additionally, lipidic compounds and proteinaceous compounds are other commonly derived natural materials which exhibit antichlamydial activity. There have also been studies exploring the efficacy of cellular metabolites and probiotics to inhibit chlamydial infections. As examples highlighting the potential of natural product-based therapeutics, three broad-spectrum antimicrobial polyherbal formulations, which exhibit potent antichlamydial activity, have been developed and studied up to Stage II clinical trials. 


\subsection{Polyphenolic Compounds}

Polyphenols are organic chemicals found in plants and have been shown to help prevent degenerative diseases and exhibit antimicrobial properties against a wide range of bacteria, including Chlamydiaceae [42]. Table 2 provides a summary of existing studies exploring the antichlamydial properties of polyphenols. The mechanism by which polyphenols have antichlamydial activity is not entirely known, however, based on these studies it appears that the antichlamydial activity of polyphenols is due to various modes of action. Results from a comprehensive study by Alvesalo et al. suggested that compound structural variations play a key role in the antichlamydial effect of polyphenolic compounds. This study evaluated the in vitro antichlamydial activity of 57 natural flavonoids and other natural polyphenols and structurally similar synthetic compounds against C. pneumoniae in human cells. Thirty-seven percent $(21 / 57)$ of the studied compounds, all of which were non-toxic to the host cells at tested concentrations, were highly active against C. pneumoniae. From the remaining compounds, $28 \%(16 / 57)$ were considered active, $11 \%(6 / 57)$ moderately active, and $24 \%(14 / 57)$ inactive (Figure 3). Even when present only before infection, some compounds had the ability to accumulate inside cells or in cell membranes, causing inhibition of C. pneumoniae [43]. From this data, there are several observations of the relationship between molecular structure and observed antichlamydial activity. Compound structural variations, either free from sugar moieties, or with greater hydrophobicity, were found to be more active.

Early studies explored a group of polyphenols found in tea, known as catechins, which have been observed to exhibit broad-spectrum antimicrobial properties [44]. It has been proposed that catechins cause cytoplasmic membrane damage by damaging [45] or disrupting the permeability [46] of lipid bilayers. Yamazaki et al., performed an in vitro study on the effect of Polyphenon 70S, a tea polyphenol extract from a green tea high in catechins, on C. pneumoniae- and C. trachomatis-infected human cells. Complete inhibition of C. pneumoniae occurred at $1.6 \mathrm{mg} / \mathrm{mL}$ Polyphenon $70 \mathrm{~S}$ for the strain AC-43 and at $0.8 \mathrm{mg} / \mathrm{mL}$ for the Ar-39 strain, and complete inhibition of C. trachomatis at $1.6 \mathrm{mg} / \mathrm{mL}$ for serovar $\mathrm{D}$ and at $0.4 \mathrm{mg} / \mathrm{mL}$ for the L2 strain. Polyphenon $70 \mathrm{~S}$ comprises: epigallocatechin, epicatechin, epigallocatechin gallate, epicatechin gallate, and gallocatechin gallate. Epigallocatechin gallate is the dominant constituent and is attributed to be a major contributor to the observed antimicrobial effects. Although Polyphenon 70S was toxic to human cells at $0.25 \mathrm{mg} / \mathrm{mL}$ for treatment post-inoculation with the bacteria, it was non-toxic when treatment began pre-inoculation [47]. A further study by Yamazaki et al. showed that five biosynthesized tea polyphenols were active against $C$. trachomatis and analyzed the varying toxicity of the catechins. All five catechins, of which (-)-epicatechin (EC) was the least toxic, had an inhibitory effect on the proliferation of $C$. trachomatis in vitro. Because the concentration of tea polyphenols required for complete inhibition of $C$. trachomatis is high compared to antibiotics, tea polyphenols are not currently suitable for treating systemic infections. Modification of the catechin structure to reduce the required dose and toxicity may help circumvent the toxicity problem for use of catechins in a topical microbicide [48].

Other antichlamydial mechanisms have also been observed with several other polyphenols. Tormakangas et al., evaluated the effects of treatment of acute C. pneumoniae infection with the flavonoids quercetin and luteolin and an alkyl gallate, octyl gallate, in a mouse model. The lowest presence of $C$. pneumoniae in lung tissue was detected in mice treated with luteolin. The response to quercetin treatment was not favorable, which contradicts other studies performed with the flavonoid [43]. C. pneumoniae is reported to inhibit apoptosis of the infected host cell and it has been proposed that luteolin negates the antiapoptotic effect of chlamydia by inducing cellular apoptosis via interference with the mitochondrial pathway $[49,50]$ and thereby allowing the chlamydial infection to become vulnerable to the hosts natural immune responses. The polyphenolic flavonoid, baicalin, also results in a more effective immune response to clear chlamydial infections. Baicalin is an antimicrobial, anti-inflammatory flavonoid isolated from Scutellariae baicalensis, or Scutellariae radix, a plant used in traditional oriental medicine and is a potential agent for therapy of $C$. trachomatis infections. Hao et al. found that baicalin can block the infection of Hep-2 cells. Treatment with baicalin began 
24 days after inoculation with $C$. trachomatis. Some antichlamydial activity was observed with baicalin concentrations between $0.12 \mathrm{mg} / \mathrm{mL}$ and $0.48 \mathrm{mg} / \mathrm{mL}$. At $48 \mathrm{mg} / \mathrm{mL}$, baicalin strongly inhibited C. trachomatis and blocked further infection almost completely. When the RFX5 and chlamydial protease-like activity factor (CPAF) genes in chlamydia-infected cells were examined, it was found that RFX5 was upregulated and CPAF was downregulated by baicalin, with CPAF as the primary target [51]. It has been suggested that the CPAF degradation of RFX5 may play a role in chlamydia escaping efficient host immune detection, and therefore the down-regulation of CPAF may allow the hosts immune system to more effectively detect the chlamydial infection [41]. The lupine-class triterpene, betulin, is extensively distributed in nature and has been shown to be highly biologically active in the treatment of intracellular pathogens. Salin et al. extracted betulin from birch bark and evaluated thirty-two betulin derivatives for potential use against C. pneumoniae in vitro. Five promising compounds were identified. The betulin derivative, betulin dioxime, had a minimum inhibitory concentration (MIC) of $1 \mathrm{mM}$ against the CWL-029 C. pneumoniae strain, with 50\% inhibition achieved at $290 \mathrm{nM}$. A clinical isolate confirmed the antichlamydial activity, with an MIC of $2.2 \mathrm{mM}$. The mechanism by which inhibition occurs is unknown [52].

Studies on extracts from two different mint species showed positive antichlamydial effects. Corn mint (Mentha arvensis) contains various phenolic compounds, with rosmarinic acid, linarin, and acacetin compounds being most prevalent. Salin et al. examined the efficacy of corn mint extracts and several pure versions of compounds present in the corn mint extracts in treating C. pneumoniae infections both in vitro and in vivo. Both the mint extracts and pure compounds exhibited high levels of inhibitory activity in vitro, with low host cell toxicity. In a mouse model, intraperitoneally administered corn mint extracts delivered at nutritionally relevant concentrations resulted in reduced inflammatory symptoms but were not as effective as antibiotics in clearing the infection [53]. Kapp et al., performed an in vitro study on the effect of seven peppermint (Mentha $\times$ piperita L.) tea extracts on C. pneumoniae-infected human cells. While all seven tea extracts were active against C. pneumoniae, at an extract concentration of $250 \mu \mathrm{g} / \mathrm{mL}$ growth inhibition varied between $20.7 \%$ and $69.5 \%$. Peppermint teas contain secondary metabolites, predominantly catechins and glycosides of flavanones and flavones, including luteolin and apigenin glycoside, which, along with rosmarinic acid, were related to higher antichlamydial activity [54].

Biochanin $\mathrm{A}$ is the main isoflavone component of red clover, and was compared with formononetin, genistein, daidzein, genistin, and daidzin for their antichlamydial effect against both $C$. trachomatis and C. pneumoniae in vitro. IC50 values ranged from 12 to $>100 \mu \mathrm{M}$ for all compounds, except formononetin and daidzein, which exhibited no inhibition of C. trachomatis. Overall, C. pneumoniae was more susceptible to inhibition. Hanski et al., determined that biochanin A exhibited the greatest antichlamydial activity overall, and significantly suppressed inclusion counts and decreased the mean bacterial inclusion size in C. trachomatis-infected cell cultures. Biochanin A prevented the formation of C. pneumoniae inclusions at concentrations of $25 \mu \mathrm{M}$ or higher and prevented the formation of new infectious progeny. The greater efficacy of biochanin A was attributed to the presence of a methylated hydroxyl group. This study went on to improve bioavailability and the resulting efficacy of biochanin A with the development of oromucosal buccal dosage forms to improve dissolution and achieve permeation of buccal tissue so as to overcome digestive demethylation and conversion to genistein [55]. 


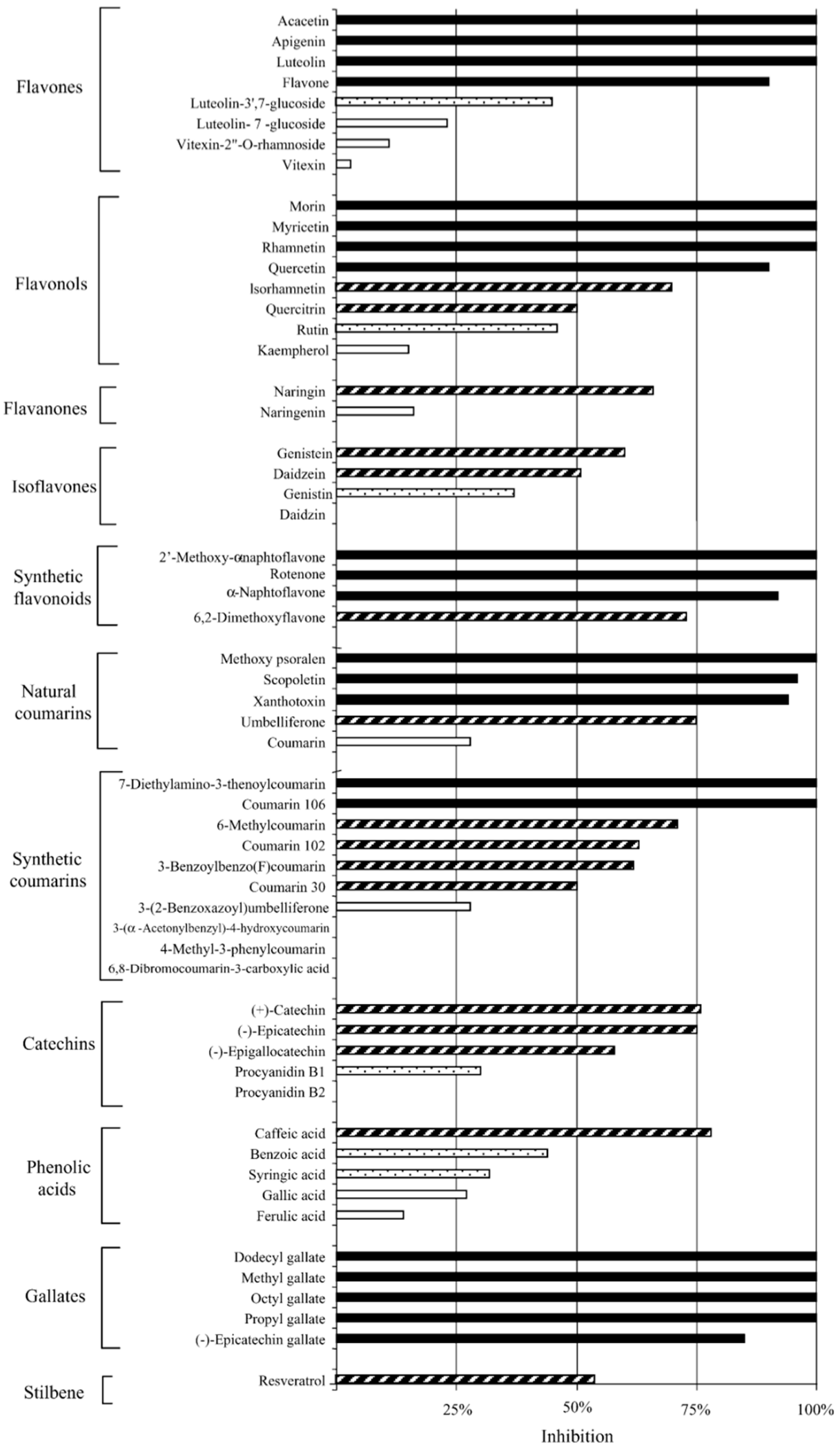

Figure 3. Inhibition percentages of various natural and synthetic polyphenolic compounds against C. pneumoniae at $50 \mu \mathrm{M}$ concentration ( $n=4$ or more). Activity is determined in comparison to controls: highly active (black bar) $=85 \%-100 \%$ inhibition; active (striped bar) $=50 \%-84 \%$; moderately active (black dotted bar) $=30 \%-49 \%$; inactive (white bar) $=<30 \%$. Adapted with permission from [43]. Copyright 2005 Elsevier Inc. 
Table 2. Past studies exploring antichlamydial properties of polyphenolic compounds.

\begin{tabular}{|c|c|c|c|c|}
\hline Antimicrobial Agent & Chlamydial Species & Study Design & Effects & Reference \\
\hline $\begin{array}{l}\text { Flavones }(\times 8) \text {, } \\
\text { Flavonols }(\times 8) \text {, } \\
\text { Flavonones }(\times 2) \text {, } \\
\text { Isoflavones }(\times 4) \\
\text { Synthetic flavonoids }(\times 4) \text {, } \\
\text { Natural coumarins }(\times 5) \text {, } \\
\text { Synthetic courmarins }(\times 10) \text {, } \\
\text { Catechins }(\times 5), \\
\text { Phenolic acids }(\times 5) \text {, } \\
\text { Gallates }(\times 5) \text {, } \\
\text { Stilbene }(\times 1)\end{array}$ & $\begin{array}{l}\text { C. pneumoniae } \\
\text { (K7) }\end{array}$ & $\begin{array}{l}\text { In vitro } \\
\text { Pre-inoculation: incubated with } \\
\text { cells for } 24 \mathrm{~h} \text { prior to } \mathrm{EB} \\
\text { inoculation. } \\
\text { Post-inoculation: administered } \\
\text { at } 0 \mathrm{~h} \text { post inoculation (p.i.). }\end{array}$ & $\begin{array}{l}\text { From } 57 \text { compounds, at } 50 \mu \mathrm{M} \text { : } 21 \text { were highly active, } 16 \text { active, } \\
6 \text { moderately active, and } 14 \text { inactive. } \\
10 \text { compounds achieved an MIC of } 50 \mu \mathrm{M} \text { or less with luteolin being } \\
8.8 \mu \mathrm{M} \text { and dodecyl gallate being } 18 \mu \mathrm{M} \text {. } \\
\text { Gallates was the most active group. } \\
\text { Some compounds accumulated inside cells or in cell membranes and } \\
\text { cause inhibition when present only prior to infection. } \\
\text { Compound structural variations, either free from sugar moieties, or } \\
\text { with greater hydrophobicity, were found to be more active. } \\
\text { All compounds were non-toxic to the host cells. }\end{array}$ & [43] \\
\hline $\begin{array}{l}\text { Polyphenon 70S: } \\
\text { Epigallocatechin (18.3\%), } \\
\text { Epicatechin }(8.6 \%), \\
\text { Epigallocatechin gallate }(35.9 \%), \\
\text { Epicatechin gallate }(11.2 \%), \\
\text { Gallocatechin gallate }(3.5 \%)\end{array}$ & $\begin{array}{l}\text { C. trachomatis } \\
\text { (D), } \\
\text { (L2) } \\
\text { C. Pneumoniae } \\
\text { (AR-39), } \\
\text { (AC-43) }\end{array}$ & $\begin{array}{l}\text { In vitro } \\
\text { Pre-treatment: incubated with } \\
\text { EBs for } 30,60 \text {, or } 90 \text { min prior to } \\
\text { inoculation. } \\
\text { Post-inoculation: administered } \\
\text { at } 0 \text { h p.i. }\end{array}$ & $\begin{array}{l}\text { Polyphenon } 70 \mathrm{~S} \text {, post-incubation, } 100 \% \text { inhibition of chlamydial } \\
\text { inclusions, at } 0.5 \mathrm{mg} / \mathrm{mL} \text {, with toxicity to host cells at } \\
0.25 \mathrm{mg} / \mathrm{mL} \text {. } \\
\text { Pre-incubation, } 100 \% \text { inhibition, at } 0.4-1.6 \mathrm{mg} / \mathrm{mL} \text {, with no toxicity } \\
\text { to host cells. }\end{array}$ & [47] \\
\hline $\begin{array}{l}\text { Catechin, } \\
\text { Epicatechin, } \\
\text { Epigallocatechin, } \\
\text { Epicatechin gallate, } \\
\text { Epigallocatechin gallate }\end{array}$ & C. pneumoniae (AR-39) & $\begin{array}{l}\text { In vitro } \\
\text { Pre-treatment: incubated with } \\
\text { EBs for } 90 \text { min prior to } \\
\text { inoculation. }\end{array}$ & $\begin{array}{l}\text { Inhibition was observed for concentrations from } 0.4 \text { to }>6.4 \mathrm{mg} / \mathrm{mL} \text {. } \\
\text { Most active compounds were epigallocatechin gallate and } \\
\text { epicatechin gallate, followed by epicatechin. } \\
\text { Catechin and epigallocatechin exhibited intermediate activity. } \\
\text { Epicatechin was the least toxic. }\end{array}$ & [48] \\
\hline $\begin{array}{l}\text { Luteolin, } \\
\text { Octyl gallate, } \\
\text { Quercetin }\end{array}$ & C. pneuтопіае (K7) & $\begin{array}{l}\text { In vivo } \\
\text { Pre- \& Post-inoculation: } \\
\text { administered daily for } 3 \text { days } \\
\text { prior to inoculation; } \\
\text { administered daily for } 12 \text { days } \\
\text { p.i. (mice) }\end{array}$ & $\begin{array}{l}\text { Luteolin suppressed inflammation in lung tissue, } C \text {. } \\
\text { pneumoniae-specific antibodies, and the presence of chlamydia in } \\
\text { lung tissue. } \\
\text { Octyl gallate had no significant effect on infection. } \\
\text { Quercetin increased the inflammatory responses and the chlamydial } \\
\text { load in the lungs. }\end{array}$ & [49] \\
\hline Baicalin & C. trachomatis $(\mathrm{D})$ & $\begin{array}{l}\text { In vitro } \\
\text { Post-inoculation: administered } \\
\text { at } 24 \text { h p.i. }\end{array}$ & $\begin{array}{l}\text { Blocks the infection of Hep- } 2 \text { cells. } \\
\text { Down-regulates the production of the chlamydia-secreted } \\
\text { protein (CPAF). } \\
\text { CPAF degradation of host transcription factors RFX5 may allow } \\
\text { chlamydia to escape efficient immune detection. } \\
\text { Baicalin may assist the host immune system to detect the } \\
\text { chlamydial infection. }\end{array}$ & [51] \\
\hline $\begin{array}{l}\text { Betulin, } \\
\text { Betulin derivatives }(\times 32)\end{array}$ & $\begin{array}{l}\text { C. pneumoniae } \\
\text { (CWL-029) }\end{array}$ & $\begin{array}{l}\text { In vitro } \\
\text { Post-inoculation: administered } \\
\text { at } 0 \text { h p.i. }\end{array}$ & $\begin{array}{l}\text { At a concentration of } 1 \mu \mathrm{M} \text {, three derivatives showed }>80 \% \text { growth } \\
\text { inhibition, and } 15 \text { compounds } 20 \%-80 \% \text { growth inhibition. } \\
\text { Betulin dioxime exhibited an MIC of } 1 \mu \mathrm{M} \text {, and achieved } 50 \% \\
\text { inhibition at } 290 \mathrm{nM} \text {. } \\
\text { Compounds were well tolerated by host cells. }\end{array}$ & {$[52]$} \\
\hline
\end{tabular}


Table 2. Cont.

\begin{tabular}{|c|c|c|c|c|}
\hline Antimicrobial Agent & Chlamydial Species & Study Design & Effects & Reference \\
\hline $\begin{array}{l}\text { Corn mint extract } \\
\text { (Mentha arvensis): } \\
\text { Rosmarinic acid }(5.2 \%) \text {, } \\
\text { Linarin }(6.0 \%) \text {, } \\
\text { Acacetin-acetylglucoside-rhamnoglycoside } \\
(2.5 \%) \\
\text { Pure compounds: } \\
\text { Rosmarinic acid, } \\
\text { Linarin, } \\
\text { Acacetin }\end{array}$ & С. pneuтопіае (CWL-029), (K7) & $\begin{array}{l}\text { In vitro } \\
\text { Post-inoculation: administered } \\
\text { at } 0 \mathrm{~h} \text { p.i. } \\
\text { In vivo } \\
\text { Pre- \& Post-inoculation: } \\
\text { administered daily for } 3 \text { days } \\
\text { prior to inoculation; } \\
\text { administered daily for } 10 \text { days } \\
\text { p.i. (mice) }\end{array}$ & $\begin{array}{l}\text { For corn mint extract, at } 256 \mu \mathrm{g} / \mathrm{mL}, 73 \% \text { inhibition of chlamydial } \\
\text { inclusions was achieved for strain CWL-029, and } 90 \% \text { for strain K7, } \\
\text { with } \sim 78 \% \text { host cell viability. } \\
\text { Pure compound, inhibition at } 100 \mu \mathrm{g} / \mathrm{mL} \text { for strain CWL-029: linarin } \\
100 \% \text {, acacetin } 97 \% \text {, and rosmarinic acid } 73 \% \text {, with } \sim 99 \% \text { host } \\
\text { cell viability. } \\
\text { Pure compound, inhibition at } 100 \mu \mathrm{g} / \mathrm{mL} \text { for strain K7: linarin } 62 \% \text {, } \\
\text { acacetin } 81 \% \text {, and rosmarinic acid } 74 \% \text {. } \\
\text { In vivo, corn mint extract in nutritionally relevant dosages resulted } \\
\text { in reduced inflammatory responses to chlamydial infection. }\end{array}$ & [53] \\
\hline $\begin{array}{l}\text { Peppermint tea extracts } \\
(\text { Mentha } \times \text { piperita } \mathrm{L} \text {.): } \\
\text { Eriocitrin, } \\
\text { 12-Hydroxyjasmonate sulfate, } \\
\text { Luteolin-O-rutinoside, } \\
\text { Rosmarinic acid, } \\
\text { Salvianolic acid B, } \\
\text { Trace polyphenols, } \\
\text { Trace plant acids }\end{array}$ & C. pneumoniae (K7) & $\begin{array}{l}\text { In vitro } \\
\text { Post-inoculation: administered } \\
\text { at } 0 \mathrm{~h} \text { p.i. }\end{array}$ & $\begin{array}{l}\text { Seven tea extracts were shown to be active against C. pneumoniae. } \\
\text { At } 250 \mu \mathrm{g} / \mathrm{mL} \text {, from } 20.7 \% \text { to } 69.5 \% \text { inhibition. } \\
\text { Higher content of luteolin and apigenin glycosides showed } \\
\text { high activity. } \\
\text { Host cell viability after the } 72 \mathrm{~h} \text { exposure to tea extracts ranged from } \\
82.4 \% \text { to } 99.4 \% \text {. }\end{array}$ & [54] \\
\hline $\begin{array}{l}\text { Isoflavones: } \\
\text { Biochanin A, } \\
\text { Formononetin, } \\
\text { Genistein, } \\
\text { Daidzein, } \\
\text { Genistin, } \\
\text { Daidzin }\end{array}$ & $\begin{array}{l}\text { C. trachomatis (K), } \\
\text { (L2) } \\
\text { C. Pneumoniae (K7) }\end{array}$ & $\begin{array}{l}\text { In vitro } \\
\text { Post-inoculation: administered } \\
\text { at } 0 \mathrm{~h} \text { p.i. }\end{array}$ & $\begin{array}{l}\text { Biochanin A at } 50 \mu \mathrm{M} \text {, complete inhibition of C. pneumoniae. } \\
\text { Biochanin A, IC50: C. trachomatis- } 62 \mu \mathrm{M} \text {; C. pneumoniae-12 } \mu \mathrm{M} \text {. } \\
\text { No harmful effects on host cell viability. } \\
\text { Biochanin A methylated hydroxyl group provides improved the } \\
\text { antichlamydial activity. } \\
\text { Biochanin A does not affect C. pneumoniae in its extracellular } \\
\text { (EB) form. } \\
\text { Oromucosal buccal dosage forms improve dissolution of biochanin A } \\
\text { and allow for permeation of porcine buccal tissue. }\end{array}$ & [55] \\
\hline $\begin{array}{l}\text { Polyphenols: } \\
\text { Quercetin, } \\
\text { Luteolin, } \\
\text { Rhamnetin, } \\
\text { Octyl gallate } \\
\text { Coadministrants: } \\
\text { Doxycycline, } \\
\text { Verapamil }\left(\mathrm{Ca}^{2+}\right), \\
\text { Isradipine }\left(\mathrm{Ca}^{2+}\right), \\
\text { Thapsigargin }\left(\mathrm{Ca}^{2+}\right)\end{array}$ & C. pneuтопіае (CWL-029) & $\begin{array}{l}\text { In vitro } \\
\text { Post-inoculation: administered } \\
\text { at } 0 \mathrm{~h} \text { p.i. }\end{array}$ & $\begin{array}{l}\text { Quercetin, luteolin, rhamnetin and octyl gallate did not improve the } \\
\text { antichlamydial effect of doxycycline. } \\
\text { Some coadministration combinations of } \mathrm{Ca}^{2+} \text { modulators with } \\
\text { phenolic compounds resulted in potentiation of the antichlamydial } \\
\text { effect of phenolic compounds. } \\
\text { More antagonistic combinations were found than synergic or } \\
\text { additive combinations. }\end{array}$ & [56] \\
\hline $\begin{array}{l}\text { Polyphenols: } \\
\text { Resveratrol, } \\
\text { Quercetin } \\
\text { Coadministrants: } \\
\text { Clarithromycin, } \\
\text { Ofloxacin }\end{array}$ & C. pneuтопіае (CWL-029) & $\begin{array}{l}\text { In vitro } \\
\text { Pre-inoculation: incubated with } \\
\text { cells for } 24 \mathrm{~h} \text { prior to } \\
\text { inoculation. }\end{array}$ & $\begin{array}{l}\text { Resveratrol at } 40 \mu \mathrm{M} \text { and quercetin at } 20 \mu \mathrm{M} \text { exhibited significant } \\
\text { growth inhibition in presence of clarithromycin or ofloxacin } \\
\text { compared to controls. } \\
\text { Immunomodulatory effects via strong inhibition of the IL-23 levels } \\
\text { with coadministration of resveratrol or quercetin and ofloxacin or } \\
\text { clarithromycin. }\end{array}$ & [57] \\
\hline
\end{tabular}


Polyphenolic synergistic effects with antibiotics or calcium modulators were explored and shown to result in improvements in antichlamydial efficacy. In an attempt to increase the efficacy of both polyphenols and doxycycline against C. pneumoniae in vitro, Salin et al. combined the polyphenols luteolin, quercetin, rhamnetin, and octyl gallate with either doxycycline or one of three calcium modulators-verapamil, isradipine, or thapsigargin. The polyphenol-doxycycline combinations did not increase the efficacy of treatment and some combinations had antagonistic effects. However, combining calcium modulators with polyphenols had some synergistic effect, although calcium modulators alone are not active against C. pneumoniae. While isradipine was synergistic with high concentrations of luteolin and quercetin, verapamil was synergistic with low concentrations of the same polyphenols. Thapsigargin had the greatest synergistic effect, significantly increasing the chlamydial growth inhibitory effect of polyphenols [56]. However, although this provides interesting insights, it should be highlighted that the synergistic use of calcium modulators in humans may lead to significant side effects. Rizzo et al. studied the synergistic effects of polyphenolic pretreatment followed by subsequent antibiotic treatment on C. pneumoniae. Either of the phenolic compounds resveratrol or quercetin was administered, followed by either clarithromycin or ofloxacin. With resveratrol concentrations of $40 \mu \mathrm{M}$ and quercetin concentrations of $20 \mu \mathrm{M}$, both phenolic compounds exhibited significant inhibitory effects when combined with clarithromycin or ofloxacin, in comparison to controls. Chlamydial inhibition was linked to the immunomodulatory effects of decreased IL-17 and IL-23 production in a time-dependent manner in C. pneumoniae-infected cells [57]. Overall, the existing studies indicate that some polyphenolic compounds directly inhibit chlamydial activity by various mechanisms and may also work synergistically with other compounds to achieve increased efficacy.

\subsection{Lipidic Compounds}

It has long been known that lipidic compounds, such as fatty acids, monoglycerides, and terpenoids, exhibit broad-spectrum antimicrobial effects [58]. Recent evidence supports that different kinds of lipidic compounds such as fatty acids and monoglycerides induce different kinds of morphological responses in lipid membranes, and hence are attractive to explore for therapeutic applications [59]. Table 3 provides a summary of existing studies that have explored the efficacy of lipidic compounds on chlamydial infections. Bergsson et al. evaluated the antichlamydial effects of 12 lipidic compounds on C. trachomatis. From these, monocaprin, lauric acid, and capric acid were shown to have the greatest antichlamydial effects. At a $5 \mathrm{mM}$ concentration, the most active, monocaprin, caused a greater than 100,000-fold inhibition of C. trachomatis when exposed for five minutes. Capric acid was the least active of the three lipids, losing most of its activity when diluted. Monocaprin at $30 \mu \mathrm{g} / \mathrm{mL}$ was 50\% effective when incubated with $C$. trachomatis for two hours. Chlamydial EBs were exposed to the lipid and then removed and inoculated into cell cultures. Observations of EBs exposed to monocaprin for 1, 5, and $10 \mathrm{~min}$, indicated that after 10 min exposure, the EBs were irreversibly deactivated and were observed to rupture and disintegrate (Figure 4A-D) [60]. These observations support the proposal that lipidic compounds primarily inactivate the bacteria by affecting and disrupting the outer membrane.

Further studies went on to explore the potential of synthetic lipids for use in developing topical microbicides. Lampe et al. determined that 2-O-octyl-sn-glycerol, a synthetic lipid developed from naturally occurring human breast milk lipids was an effective inhibitory agent against $C$. trachomatis. Complete growth inhibition occurred after two hours of contact with a $7.5 \mathrm{mM}$ concentration of 2-O-octyl-sn-glycerol. Four other lipids were studied, but were significantly less effective. When tested in conditions similar to the human vagina-10\% human blood and with $\mathrm{pH}$ alterations between 4.0 and 8.0-lipid activity was not affected. When EBs were exposed to lipids for 90 min, the EBs appeared to be hollow shells with ruptured cell walls (Figure 4E,F). All of these lipids have also been shown to exhibit broad-spectrum antimicrobial properties [61], which supports cell wall disruption being the primary mechanism of action. However, it should be noted that these synthetic lipids were determined to exhibit no cellular toxicity, and preliminary observations indicate no vaginal irritation in rabbit 
models from lipid concentrations as high as $120 \mathrm{mM}$ [62]. As a continuation of the work done in 1998 by Lampe et al., Skinner et al. explored the development of a topical microbicide with the synthetic lipid, 3-O-octyl-sn-glycerol [3-OG], and an engineered antimicrobial peptide, WLBU2, as the active compounds. After in vitro activity and toxicity analysis of the components, concentrations found to be toxic were omitted from further tests. While both WLBU2 and 3-OG were effective in vitro against $C$. trachomatis, the two components combined showed synergy, with significantly increased inhibitory activity. Although simulated fluids reduced activity, the combination shows potential for the development of a topical microbicide [63].

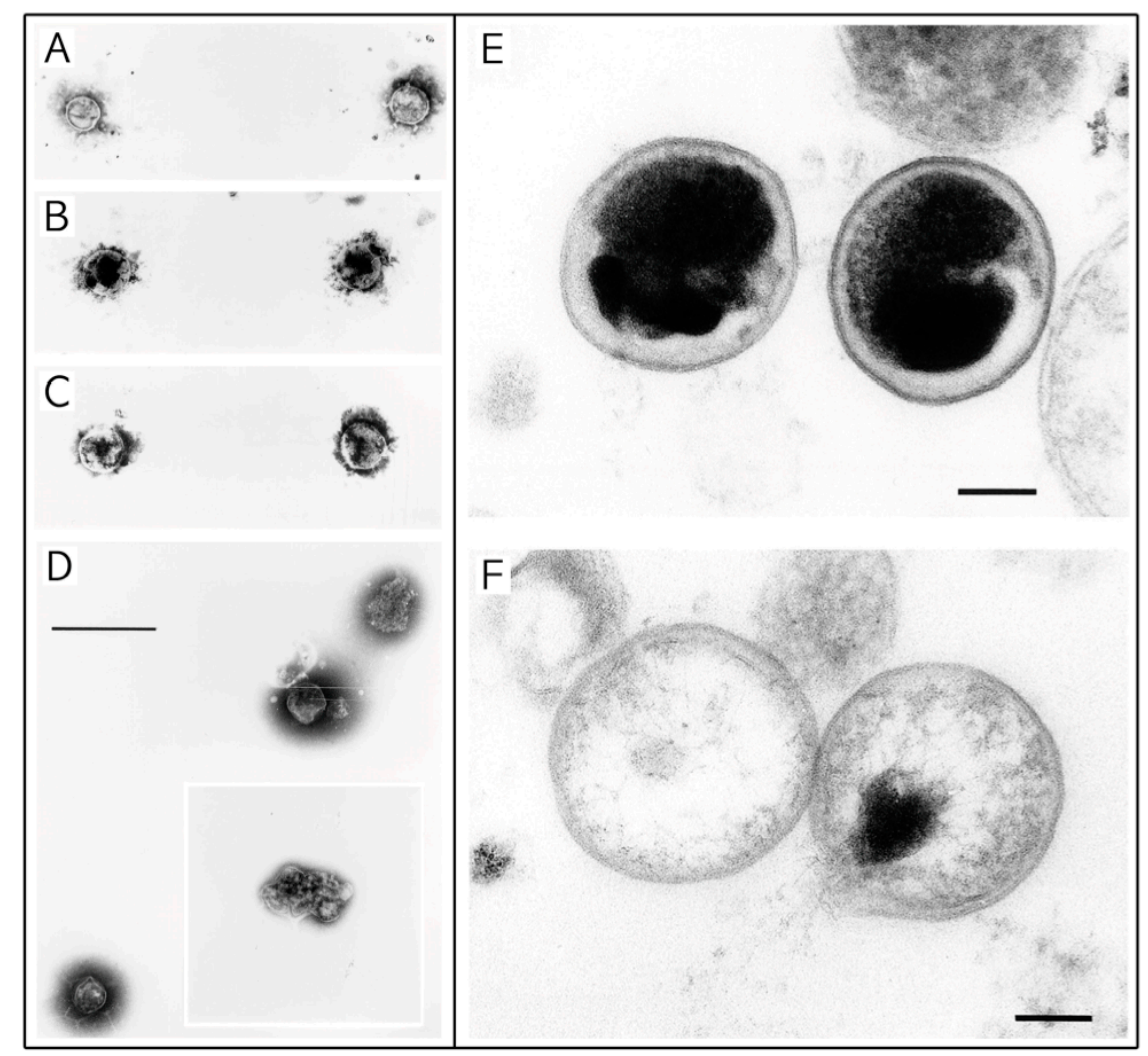

Figure 4. Scanning electron microscopy images of $C$. trachomatis with and without exposure to lipidic compounds. (A-D) Exposure of C. trachomatis EBs to monocaprin; The EBs were untreated (A) or treated with $10 \mathrm{mM}$ monocaprin for $1 \mathrm{~min}(\mathbf{B}) ; 5 \mathrm{~min}(\mathbf{C})$; and $10 \mathrm{~min}(\mathbf{D})$; With $10 \mathrm{~min}$ exposure the EBs appear deformed or disrupted (D, inset); Bars, $1 \mu \mathrm{m}$. (E,F) Exposure of C. trachomatis EBs to 1-O-hexyl-sn-glycerol; (E) C. trachomatis EBs exposed to sucrose-phosphate-glutamine buffer (SPG) only; (F) EBs exposed to $50 \mathrm{mM}$ 1-O-hexyl-sn-glycerol for $90 \mathrm{~min}$ appear as hollow structures. Parts (A-D) are adapted with permission from [60]. Copyright 1998 American Society for Microbiology. Parts E and $\mathrm{F}$ are adapted with permission from [62]. Copyright 1998 American Society for Microbiology.

Another lipidic compound shown to have potential for topical application formulations is a tropolone-related compound, hinokitiol, which is found in the heartwood of trees in the Cupresseceae family. Hinokitiol has previously been shown to have antimicrobial activity against several bacterial species, including Staphylococcus aureus and Schistosoma mansoni. Yamano et al. studied the inhibitory effects of hinokitiol on C. trachomatis. Although, hinokitiol was found to be active against C. trachomatis, with an MIC of $32 \mu \mathrm{g} / \mathrm{mL}$ in vitro, the MIC was significantly greater than for hinokitiol against $S$. aureus or the MICs of antibiotics. Because high concentrations of hinokitiol are cytotoxic, topical application would be recommended for treatment of $C$. trachomatis infections [64]. While there are only a few studies exploring the antichlamydial efficacy of lipidic compounds, the results support the widely held opinion that lipidic compounds typically exhibit broad-spectrum antimicrobial properties, which is 
primarily due to disrupting the cellular membrane of pathogenic microbes. This supports the potential antichlamydial activity of a wide range of unexplored lipidic compounds, and highlights the need for ongoing research in this field.

Table 3. Past studies exploring antichlamydial properties of lipidic compounds.

\begin{tabular}{|c|c|c|c|c|}
\hline Antimicrobial Agent & $\begin{array}{l}\text { Chlamydial } \\
\text { Species }\end{array}$ & Study Design & Effects & Reference \\
\hline $\begin{array}{l}\text { Caprylic acid, } \\
\text { Capric acid, } \\
\text { Lauric acid, } \\
\text { Myristic acid, } \\
\text { Palmitoleic acid, } \\
\text { Oleic acid, } \\
\text { 1-monoglyceride of } \\
\text { each fatty acid }\end{array}$ & $\begin{array}{l}\text { C. trachomatis } \\
(\mathrm{K})\end{array}$ & $\begin{array}{l}\text { In vitro } \\
\text { Pre-treatment: } \\
\text { incubated with EBs for } \\
1,5,10 \text {, or } 120 \mathrm{~min} \\
\text { prior to inoculation. }\end{array}$ & $\begin{array}{l}\text { Lauric acid, capric acid, and } \\
\text { monocaprin caused }>10,000 \text {-fold } \\
\text { reduction in the infectivity titer. } \\
\text { Monocaprin was the most active, with } \\
>100,000 \text {-fold inactivation of } \\
\text { C. trachomatis at a concentration of } \\
5 \mathrm{mM} \text { for } 5 \text { min. } \\
\text { Results indicate that bacteria are } \\
\text { killed by disrupting membranes of } \\
\text { chlamydial elementary bodies. }\end{array}$ & {$[60]$} \\
\hline $\begin{array}{l}\text { 1-O-octyl-, } \\
\text { 2-O-octyl-, } \\
\text { 1-O-heptyl-, } \\
\text { 1-O-hexyl-, } \\
\text { 2-O-hexyl-sn-glycerol }\end{array}$ & $\begin{array}{l}\text { C. trachomatis } \\
\text { (D), } \\
\text { (F) }\end{array}$ & $\begin{array}{l}\text { In vitro } \\
\text { Pre-treatment: } \\
\text { incubated with EBs for } \\
0,30,60,90 \text {, or } 120 \text { min } \\
\text { prior to inoculation. }\end{array}$ & $\begin{array}{l}\text { 2-O-octyl-sn-glycerol, at } 7.5 \mathrm{mM} \text {, } \\
\text { completely prevented growth of } \\
\text { C. trachomatis after } 120 \text { min of contact } \\
\text { with the organism. } \\
\text { The lipids were shown to have } \\
\text { disrupted the chlamydial inner } \\
\text { membrane, allowing leakage of the } \\
\text { cytoplasmic contents from the cell. }\end{array}$ & {$[62]$} \\
\hline $\begin{array}{l}\text { Lipidic compound: } \\
\text { 3-O-octyl-sn-glycerol } \\
\text { Coadministrant: } \\
\text { Antimicrobial peptide } \\
\text { (WLBU2) }\end{array}$ & $\begin{array}{l}\text { C. trachomatis } \\
\text { (D), } \\
\text { (E), } \\
\text { (L2) }\end{array}$ & $\begin{array}{l}\text { In vitro } \\
\text { Pre-treatment: } \\
\text { incubated with EBs for } \\
5 \text { or } 120 \text { min prior } \\
\text { to inoculation. }\end{array}$ & $\begin{array}{l}\text { 3-O-octyl-sn-glycerol, at } 6.25 \mathrm{mM} \text {, } \\
\text { was } 100 \% \text { inhibitory after } 5 \mathrm{~min} \\
\text { of exposure. } \\
\text { Coadministration with WLBU2 } \\
\text { produces significantly } \\
\text { increased activity. } \\
\text { 3-O-octyl-sn-glycerol could be used at } \\
\text { up to } 30 \mathrm{mM} \text { without causing toxicity. }\end{array}$ & [63] \\
\hline Hinokitiol & $\begin{array}{l}\text { C. trachomatis } \\
\text { (D) }\end{array}$ & $\begin{array}{l}\text { In vitro } \\
\text { Pre-treatment: } \\
\text { incubated with EBs for } \\
1 \text { h prior to inoculation. } \\
\text { Post-inoculation: } \\
\text { administered at } 0 \text { h p.i. }\end{array}$ & $\begin{array}{l}\text { Hinokitiol, was shown to have } \\
\text { an MIC and minimum lethal } \\
\text { concentration (MLC) of } 32 \mu \mathrm{g} / \mathrm{mL} \text {. } \\
\text { High concentrations of hinokitiol } \\
\text { have been shown to be cytotoxic. }\end{array}$ & [64] \\
\hline
\end{tabular}

\subsection{Proteinaceous Compounds}

There is a wide range of proteinaceous compounds known to exhibit antimicrobial effects. Table 4 summarizes existing studies reporting protein-based antichlamydial compounds. An early reference to the use of desert truffle (Terfezia claveryi) aqueous extracts in treating trachoma, a common eye disease resulting from a $C$. trachomatis infection, highlights the importance of exploring ethnobotanical therapeutics as leads for new antimicrobial compounds. Desert truffles are a mycorrhizal fungus, or dark brown truffle, native to the Arabian Peninsula, and are a traditional ethnobotanical medicine in Bahrain. A protein extracted from T. claveryi has displayed antimicrobial activity against a wide spectrum of bacteria and against $C$. trachomatis in particular. In a pilot clinical study conducted by Al-Marzooky in 1981, which used sterilized aqueous extracts of T. claveryi to treat patients with trachoma, the truffle extracts were found to be effective, although slower acting than conventional antibiotic treatment. The treatment that most effectively inhibited C. trachomatis was with partially purified proteins extracted from an aqueous extract of T. claveryi. Effective in treating a broad range of bacterial infections as well as other diseases, T. claveryi and other species of desert truffles have many potential uses in medicine in addition to treating C. trachomatis [65].

Peptides comprise short chains of amino acids and are a common form of antimicrobial proteinaceous compounds. There is significant research indicating the broad-spectrum antimicrobial properties of various peptide classes. During studies in the mid-1990s, Yasin et al. explored the 
antichlamydial properties of human defensin HNP-2 and porcine protegrin PG-1 against C. trachomatis in vitro. Both HNP-2 and PG-1 inhibited chlamydial infection, but HNP-2 was the most potent. Examination of PG-1 treated EBs revealed morphological changes, membrane damage, and loss of cytoplasmic contents [66]. Later, melittin, as a principle active component of bee venom, was explored by Lazarev et al. to develop a potential treatment for C. trachomatis infections. Chlamydial inhibition was achieved in vitro with the introduction and activation of recombinant plasmid vectors expressing the melittin gene. Melittin is known to be cytotoxic and it is believed that the main antichlamydial mechanism is its direct cytotoxic effect, however, a secondary mechanism may be due to lowering the transmembrane potential of a transfected cell, which disturbs chlamydial adhesion to the cell [67]. During in vivo mouse studies, half of infected mice were free from infection 3-4 weeks after exposure [68].

Cecropin is a peptide found in cecropia moths (Hyalophora cecropia) that has been shown to have broad-spectrum antimicrobial activity. As part of the development of a cecropin-based topical microbicide, Ballweber et al. determined the minimum bactericidal concentration (MBC) of gel formulations of cecropin peptides D2A21 and D4E1 for in vitro activity against C. trachomatis. The gel formulations were equally effective against two $C$. trachomatis strains and the addition of $10 \%$ human blood did not alter the results significantly. Although $\mathrm{pH}$ values above and below 7 reduced D2A21 activity, the $2 \%$ D2A2 gel formulation remained effective with experimental $\mathrm{pH}$ variation. After D2A21 exposure for $90 \mathrm{~min}$, ultrastructural observations showed that $C$. trachomatis EB membranes had been disrupted, causing the leaking of cytoplasm (Figure 5A,B) [69]. Previous studies have also suggested that this class of peptides inhibits microbial growth due to the creation of pores or channels through the bacterial membrane $[70,71]$. However, other studies suggest that similar peptides exhibit broad-spectrum microbial inhibitory activity due to the release of mitochondrial respiratory control, the inhibition of protein import, and the inhibition of bacterial respiration [72]. In an extension of the work done by Ballweber et al., as mentioned above, Skinner et al. explored the development of a topical microbicide with a synthetic lipid, 3-OG, and an engineered antimicrobial peptide, WLBU2. Both WLBU2 and 3-OG were effective in vitro against C. trachomatis, however, when combined, the two components together showed significantly increased inhibitory effect [63].

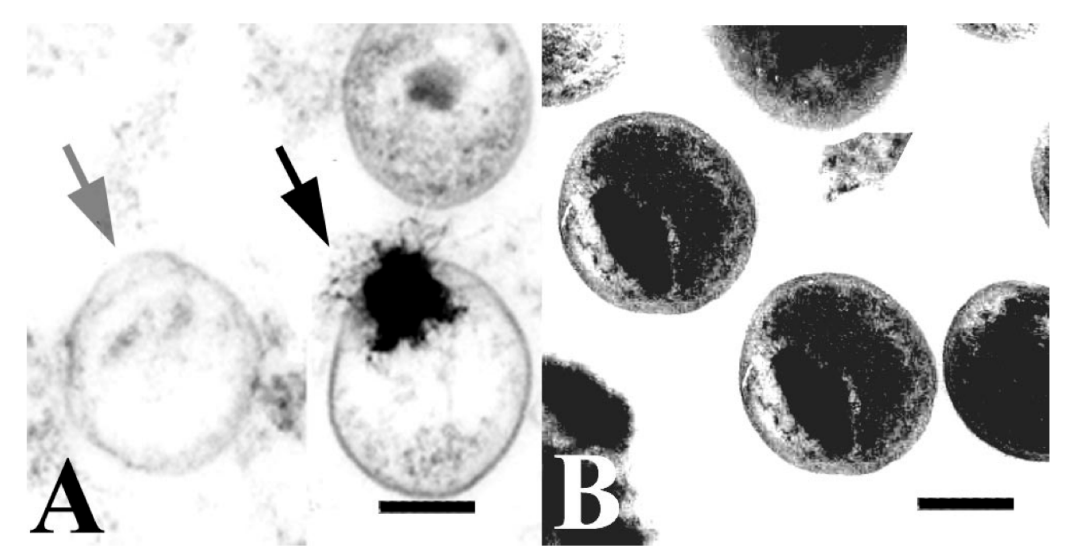

Figure 5. Scanning electron microscopy images of $C$. trachomatis exposed to cecropin peptide D2A21 for $90 \mathrm{~min}$. (A) Organisms treated with D2A21 appear to be hollow or in the process of leaking their cytoplasmic contents (black arrow); (B) Untreated organisms incubated in SPG only. Bar $=0.5 \mu \mathrm{m}$. Adapted with permission from [69]. Copyright 2002 American Society for Microbiology.

Granulocyte- and epithelium-derived antimicrobial peptides, protegrin-1, RTD-1, cryptdin-4, and indolicidin, were studied by Chong-Cerrillo et al. in vitro. Protegrin-1 was found to have the strongest antichlamydial activity, inhibiting infectivity by $50 \%$ at a concentration of $6 \mu \mathrm{g} / \mathrm{mL}$. Several chlamydial serovars were examined and results suggested that specific peptide/bacteria interactions are complex 
and remarkably specific. Overall, it was observed that protegrins may have a broader antimicrobial activity than defensins [73]. Then, in a highly comprehensive study by Yasin et al., 48 structurally diverse antimicrobial peptides were examined against $C$. trachomatis serovar L2. By examining both natural and synthetic peptides from five major peptide groups: full-length $\beta$-sheet $(\times 13)$, truncated protegrins $(\times 7)$, PG-1 disulfide variants $(\times 7)$, $\alpha$-helical peptides $(\times 12)$, and circular peptides $(\times 6)$, it was possible to gain insight into some general properties regarding the antichlamydial properties of peptides. From this, it was proposed that moderate-sized cationic peptides may be useful in microbicide preparations designed to prevent chlamydial infection [74].

Cathelicidin peptides are found in lysosomes of macrophages and polymorphonuclear leukocytes (PMNs), and keratinocytes. In an important series of studies, Donati et al. explored the antichlamydial characteristics of cathelicidin peptides from various sources upon a wide range of chlamydial species. Initially, the cathelicidin peptides: SMAP-29 (sheep), LL-37 (humans), BMAP-27 (cattle), BMAP-28 (cattle), BAC-7 (cattle), and PG-1 (pigs), were tested against a total of 25 strains from the chlamydial species: C. trachomatis, C. pneumoniae, C. felis, C. abortus, C. psittaci, and C. pecorum. It was observed that: (1) SMAP-29 was most active against $C$. trachomatis, and was also active against $C$. pneumoniae and C. felis; (2) C. pneumoniae strains were less susceptible to peptides than C. trachomatis; (3) most animal Chlamydiae were not sensitive to cathelicidins at concentrations of around 10 to $80 \mu \mathrm{g} / \mathrm{mL}$; and (4) PG-1 resulted in an increase in the number of inclusions in some animal chlamydial species at a concentration of $80 \mu \mathrm{g} / \mathrm{mL}$ [75]. In a follow-up study, the same group of peptides was examined against nine $C$. suis isolates obtained from pigs with conjunctivitis. Again, SMAP-29 was most active, followed by BAC-7 and BMAP-27, with LL-37 and PG-1 showing no activity at $80 \mu \mathrm{g} / \mathrm{mL}$ [76]. Next, to further explore the earlier observation that PG-1 resulted in increased activity in some animal chlamydial species, Donati et al. more carefully explored the effect of PG-1 on C. abortus infectivity. From this it was identified that infection of PG-1-pretreated cells resulted in an eight-fold increase in the number of inclusions and that PG-1 treatment after chlamydial infection had no increase in infectivity. Additional experiments demonstrated that PG-1 pretreatment facilitates the entry of C. abortus into host cells [77].

Dermaseptins are a family of peptides isolated from skin of the Phyllomedusa genus of frogs. Bergaoui et al. performed an in vitro evaluation of antichlamydial and cytotoxic properties of dermaseptin $\mathrm{S}_{4}$ and derivatives: $\mathrm{D}_{4} \mathrm{D}_{20} \mathrm{~S}_{4}, \mathrm{~K}_{4} \mathrm{~K}_{20} \mathrm{~S}_{4}, \mathrm{~S}_{4}(5-28)$, and $\mathrm{S}_{4}$ (1-12). $\mathrm{S}_{4}$ provided 81\% inhibition after $48 \mathrm{~h}$ at a concentration of $5 \mu \mathrm{g} / \mathrm{mL}$, whereas $\mathrm{K}_{4} \mathrm{~K}_{20} \mathrm{~S}_{4}$ provided $96 \%$ inhibition after $48 \mathrm{~h}$ at $5 \mu \mathrm{g} / \mathrm{mL}$. The 50\% cytotoxic concentration (CC50) was determined to be higher than $25 \mu \mathrm{g} / \mathrm{mL}$ for each peptide, except for $\mathrm{S}_{4}$, which appeared to be more toxic than the other peptides. However, increasing the number of peptide positive charges reduced cytotoxicity [78]. Overall, there is a wealth of information regarding peptide/Chlamydiae interactions that could be used for the further development of peptide-based antichlamydial therapeutics.

Transferrins are a family of iron-binding glyco-proteins found in milk, tears, saliva, and vaginal secretions that have been shown to be both bactericidal and bacteriostatic [79]. A series of studies was performed to explore the efficacy of various transferrins on inhibiting poultry-related C. psittaci infections. Initially, Beeckman et al. tested the effect of ovotransferrin (ovoTF), human lactoferrin (hLF), and bovine lactoferrin (bLF) against $C$. psittaci in vitro. While all three transferrins exhibited inhibitory activity, ovoTF was more effective in inhibiting irreversible attachment and cell entry by C. psittaci, though transferrins had no effect on bacterial activity within eukaryotic cells. The antichlamydial activity of ovoTF is believed to stem from ovoTF incorporation into the bacterial membrane, followed by subsequent binding of bacterial lipopolysaccharides leading to the bacterial membrane becoming more rigid. It is proposed that increased membrane rigidity results in interference with the actin host cell recruitment pathway by disrupting the stability of bacterial T3SS translocon proteins, or by disrupting secretion of Type III secretion effector proteins. Additionally, interference with the actin host cell recruitment pathway may occur due to proteolytic degradation of the Type III secretion effector proteins. Such disruption of the actin host cell recruitment pathway is believed to inhibit 
actin host cell recruitment at the bacterial entry site, which is a key step in host cell internalization of the bacteria [80]. In a follow-up study, Van Droogenbroeck et al. investigated using ovoTF to prevent $C$. psittaci infections by treating turkeys with aerosolized ovoTF, and then inoculating the turkeys with a virulent strain of $C$. psittaci. While the ovoTF did not prevent infection, the severity of infection was significantly diminished. It is proposed that iron sequestration is involved in the in vivo antibacterial activity of ovoTFs and may also be the underlying mechanism which results in ovoTFs activating both innate and adaptive immune responses [81]. In a later study, newborn turkeys infected with C. psittaci, avian metapneumovirus, or Ornithobacterium rhinotracheale were treated with ovoTF. For the first nine weeks, the turkeys remained healthy, after which symptoms of respiratory disease appeared. OvoTF treatment reduced the shedding of C. psittaci into the air, reducing the risk of zoonotic transmission, and respiratory disease was delayed for the first half of the brood period, resulting in a $46 \%$ reduction in mortality. Although infection was not prevented, the symptoms of infection were less severe and the cost of antibiotics required for treatment lowered. As the C. psittaci infection was not cured, ovoTF is currently recommended for use in conjunction with antibiotics unless further studies increase the effectiveness of ovoTF [82]. These studies highlight the potential diversity in antimicrobial efficacy and mechanism of action for proteinaceous compounds. While transferrins can disrupt the biological pathways necessary for host cell infection, peptides have been shown to rupture the membrane of infective EBs thereby leading to bacterial lysis and death.

Table 4. Past studies exploring antichlamydial properties of proteinaceous compounds.

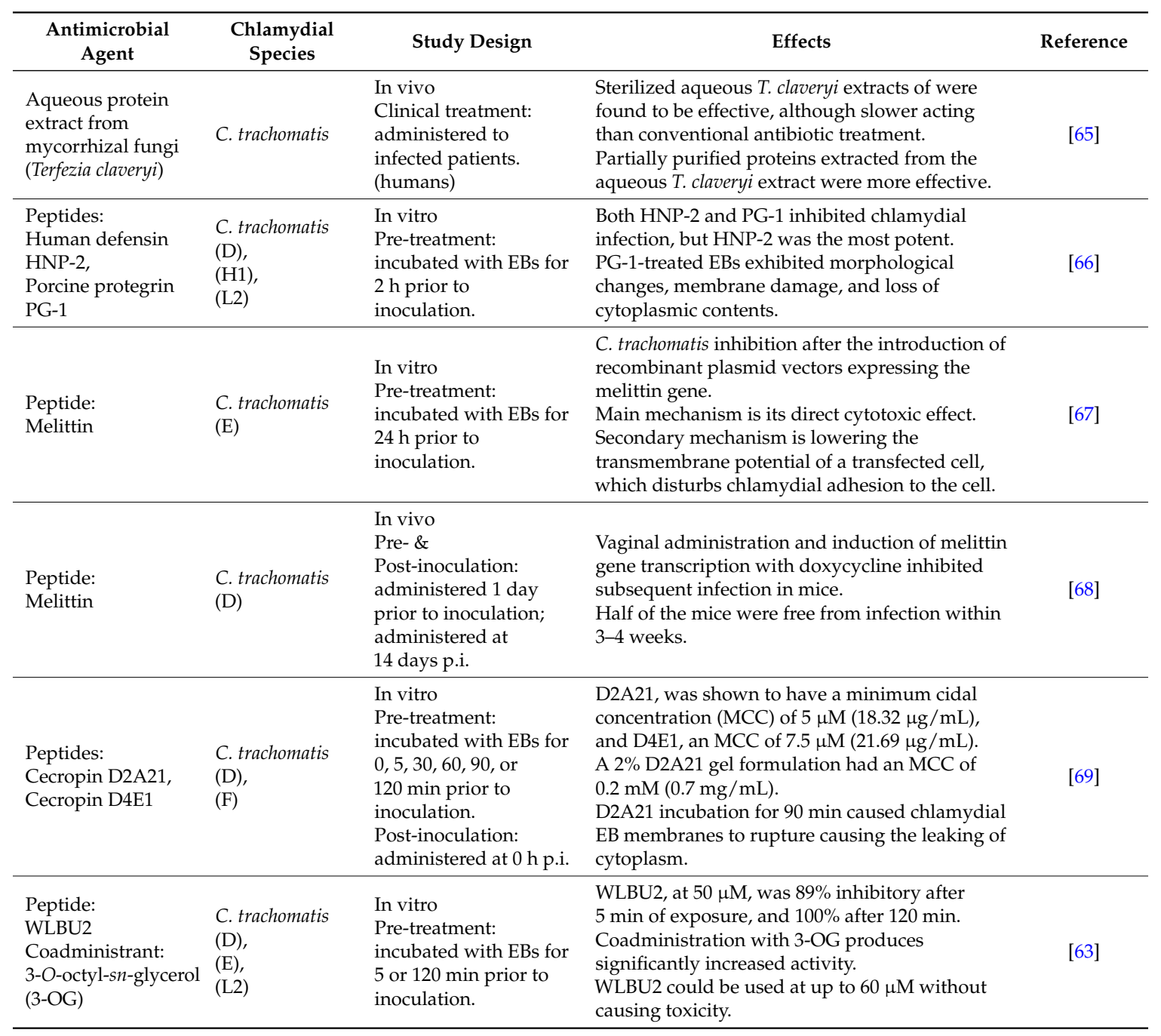


Table 4. Cont.

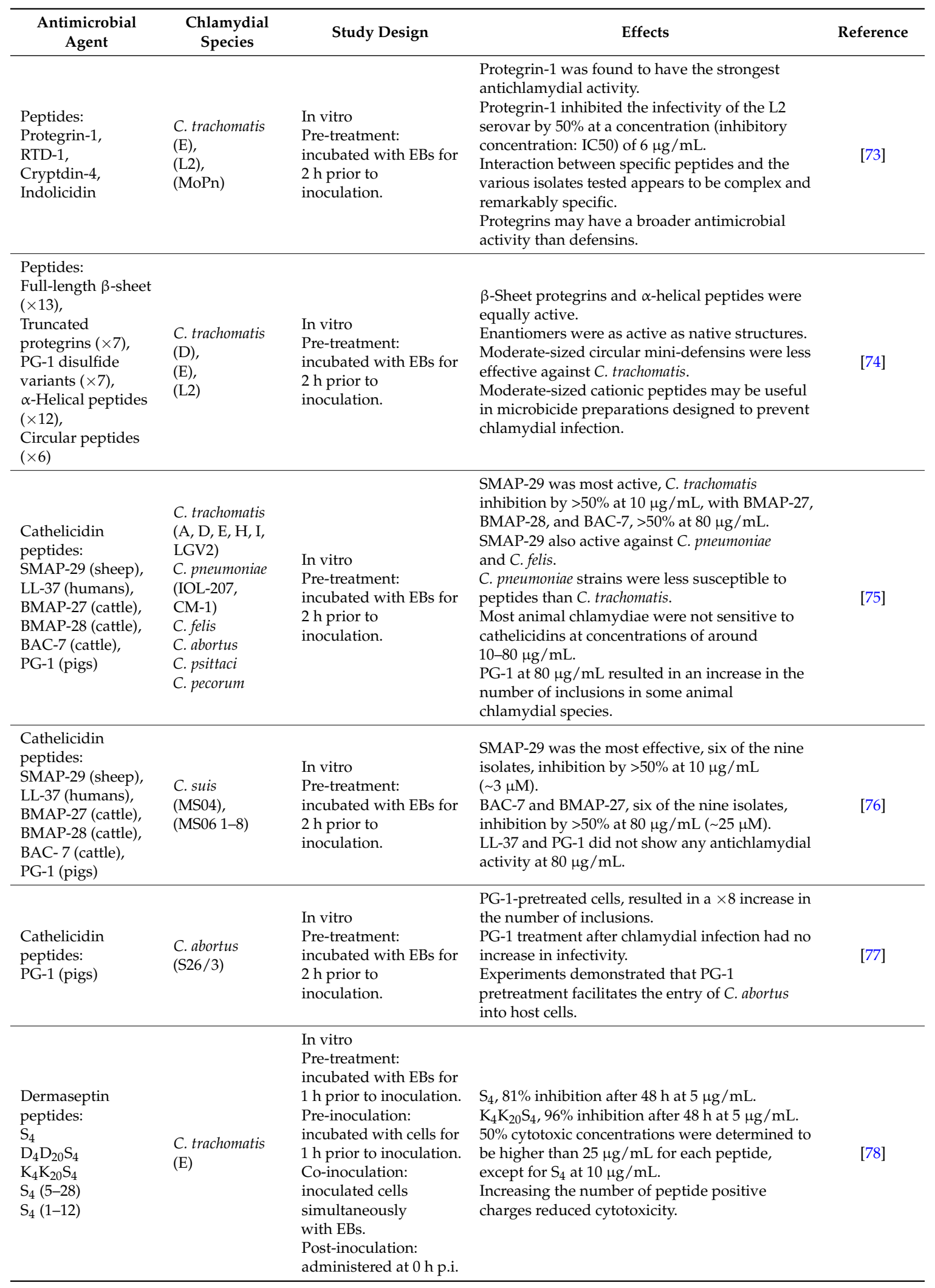


Table 4. Cont.

\begin{tabular}{|c|c|c|c|c|}
\hline $\begin{array}{c}\text { Antimicrobial } \\
\text { Agent }\end{array}$ & $\begin{array}{l}\text { Chlamydial } \\
\text { Species }\end{array}$ & Study Design & Effects & Reference \\
\hline $\begin{array}{l}\text { Transferrins: } \\
\text { Ovotransferrin, } \\
\text { Human lactoferrin, } \\
\text { Bovine lactoferrin }\end{array}$ & $\begin{array}{l}\text { C. psittaci } \\
\text { (D) }\end{array}$ & $\begin{array}{l}\text { In vitro } \\
\text { Pre-treatment: } \\
\text { incubated with EBs for } \\
1 \mathrm{~h} \text { prior to inoculation. } \\
\text { Post-inoculation: } \\
\text { administered at } 3 \mathrm{~h} \text { p.i. }\end{array}$ & $\begin{array}{l}\text { Ovotransferrin, pre-incubation, at } 0.5-5 \mathrm{mg} / \mathrm{mL} \text {, } \\
\text { prior to infecting BGM cells significantly lowered } \\
\text { infection rates. } \\
\text { Ovotransferrin was more effective than human } \\
\text { and bovine lactoferrin in inhibiting bacterial } \\
\text { irreversible attachment and cell entry. }\end{array}$ & [80] \\
\hline $\begin{array}{l}\text { Transferrin: } \\
\text { Ovotransferrin }\end{array}$ & $\begin{array}{l}\text { C. psittaci } \\
\text { (D), } \\
\text { (F), } \\
\text { (E/B) }\end{array}$ & $\begin{array}{l}\text { In vivo } \\
\text { Prophylaxis: from } \\
2 \text { weeks old, } \\
\text { administered daily for } \\
12 \text { days. (turkeys) }\end{array}$ & $\begin{array}{l}\text { A daily } 5 \mathrm{mg} \text { dose for } 12 \text { days prevented any } \\
\text { symptoms of } C \text {. psittaci infection in turkeys. } \\
\text { Respiratory disease occurred at } 9 \text { weeks } \\
\text { although, overall treatment was associated with } \\
46 \% \text { reduction of mortality. }\end{array}$ & [82] \\
\hline
\end{tabular}

\subsection{Cellular Metabolites \& Probiotics}

Mechanisms of immune response in controlling microbial infections and the complex interplay between symbiotic host microbiota and pathogenic microbes are important considerations in the development of new treatment strategies. Table 5 summarizes results of investigations into the effect of cellular metabolites and probiotic microbes with regards to chlamydial infections. Carratelli et al. explored the role of the cellular metabolite, nitric oxide (NO), in inhibiting C. pneumoniae from infecting macrophage J774 cells, as well as the ability of NO to directly damage isolated C. pneumoniae cells. Infected cells were exposed to recombinant murine gamma interferon (MurIFN- $\gamma$ ) so as to activate inducible nitric oxide synthase (iNOS). This resulted in increased production of NO and reduced viability of the infected cells. In addition, 2-( $N, N$-diethylamino)-diazenolase-2-oxide was added to cells before infection or during chlamydial cultivation. 2-( $N, N$-diethylamino)-diazenolase-2-oxide is a complex of diethylamine with $\mathrm{NO}$, which can be used to generate a controlled release of $\mathrm{NO}$ in solution. The increase in NO concentration, before cell infection or during chlamydial cultivation, resulted in C. pneumoniae inhibition in a dose-dependent manner. These results suggest that the host immune response to chlamydial infection triggers cellular pathways which activate NO release and subsequently lead to the inhibition of chlamydial growth [83]. Cellular NO production also has implications for the role of symbiotic microbes in the control of pathogenic microbial infections, as a wide range of host symbiotic microbiota are known to produce $\mathrm{NO}$ as a cellular metabolite [84].

A growing trend in research is the role of symbiotic microbes in human health and results indicate that the host microbiome plays a significant role in the inhibition of pathogenic microbial infections. Pollmann et al. explored the efficacy of probiotic feed supplements to reduce rates of chlamydial congenital infections in swine. However, C. suis isolate, S-45, is identical to C. trachomatis serovar D, and consequently is a concern for zoonotic infection, such that limiting the spread of C. suis infection in swine is important for human safety. The large-scale antibiotic treatment of swine is undesirable, which has led to much interest in the development of alternative treatments. Enterococcus faecium is a bacterium that has previously shown beneficial effects as a probiotic feed supplement. When Pollmann et al. used E. faecium as a probiotic in the feed of pregnant $C$. suis-positive sows for thirteen weeks and then for eight weeks after giving birth, the rate of piglets born infected was reduced from $85 \%$ to $60 \%$ and the appearance of infection was delayed. The Pollman et al. study was the first to test the effect of probiotics on an obligate intracellular bacteria. It was proposed that E. faecium may function as an antibiotic by reducing the proliferation of bacteria, inhibiting host cell 
infection, or facilitating a more rapid clearance of the infection. Additionally, as a probiotic, E. faecium is expected to balance the native microbial population of the swine digestive tract, which is beneficial for maintaining the hosts innate defense system [85].

To gain greater insight into the mechanism by which probiotic bacteria may exhibit antichlamydial activity, there are several studies which explore the antichlamydial effect of various lactobacilli on C. trachomatis. Mastromarino et al. explored the antichlamydial effects of the vaginal lactobacilli, Lactobacillus brevis and Lactobacillus salivarius, on C. trachomatis. Both lactobacilli had an adverse effect on chlamydial EBs, on chlamydial adsorption to epithelial cells, and on intracellular phases of chlamydial replication, although $L$. brevis was significantly more effective than $L$. salivarius. Significantly, L. brevis inhibited the development of persistent forms of $C$. trachomatis induced by coinfection with herpes simplex virus type 2 (HSV-2) [86]. Gong et al. went on to explore the mechanism of lactobacilli antichlamydial properties on C. trachomatis by preparing and testing lactobacillus-conditioned media (LCM) from Lactobacillus crispatus, Lactobacillus gasseri, and Lactobacillus jensenii. The LCM from each of the lactobacillus strains exhibited similar inhibitory activity. Through $\mathrm{pH}$ analysis and modification of the LCM, chlamydial inhibition was shown to be due to acidic $\mathrm{pH}$ conditions arising from lactic acid production. As another cellular metabolite of interest, $\mathrm{H}_{2} \mathrm{O}_{2}$, was shown to not inhibit chlamydial activity at levels present in the LCM [87]. Rizzo et al., explored the ability of L. crispatus to influence the infectivity of C. trachomatis. HeLa and J774 cells were infected with C. trachomatis and exposed to L. crispatus and its supernatant. It was determined that L. crispatus and its supernatant had no cytotoxic effect on the epithelial cells or macrophages. Importantly, L. crispatus and its supernatant inhibited the adhesion of $C$. trachomatis cells to human epithelial cells or macrophages, and inhibited C. trachomatis infectivity. The immunomodulatory effect of L. crispatus was evaluated by variations in the expression of inflammatory cytokines, IL-6, IL-8, TNF- $\alpha$, and IL-10. It was observed that L. crispatus and its supernatant reduced the production of the pro-inflammatory cytokines, IL-6, IL-8, and TNF- $\alpha$. In contrast, L. crispatus and its supernatant significantly increased the production of the anti-inflammatory cytokine, IL-10. L. crispatus commonly resides in the urogenital microbiome of healthy women and these results suggest that increasing the presence of such microbes can play an important role in protecting the genitourinary tract against pathological conditions [88]. Nardini et al. performed a comprehensive study of eight strains of L. crispatus, six strains of L. gasseri, three strains of Lactobacillus vaginalis, and lactic acid as a lactobacilli cellular metabolite, on the infectivity of C. trachomatis. All lactobacilli exerted a strong inhibitory effect, although, L. crispatus exhibited the highest efficacy. Greater antichlamydial activity was correlated to increased cellular metabolites resulting in a lower $\mathrm{pH}$, and the acidic conditions produced by lactic acid production were shown to be necessary for chlamydial inhibition. However, lactobacilli supernatants exhibited greater inhibition than only lactic acid, suggesting synergism with other lactobacilli metabolites. Interestingly, both shorter EB/lactobacilli supernatant incubation times, as well as increased lactobacilli consumption of glucose by the most active strains, were related to higher inhibitory activity [89]. Overall, these studies indicate the potential of a range of probiotics in inhibiting and managing chlamydial infections. 
Table 5. Past studies exploring antichlamydial properties of cellular metabolites \& probiotics.

\begin{tabular}{|c|c|c|c|c|}
\hline $\begin{array}{c}\text { Antimicrobial } \\
\text { Agent }\end{array}$ & $\begin{array}{l}\text { Chlamydial } \\
\text { Species }\end{array}$ & Study Design & Effects & Reference \\
\hline Nitric oxide & C. pneumoniae & $\begin{array}{l}\text { In vitro } \\
\text { Pre-treatment: incubated } \\
\text { with EBs for } 2 \mathrm{~h} \text { prior } \\
\text { to inoculation. } \\
\text { Co-inoculation: } \\
\text { inoculated cells } \\
\text { simultaneously with EBs. }\end{array}$ & $\begin{array}{l}\text { Increases in nitric oxide (NO) } \\
\text { concentration resulted in } \\
\text { chlamydial inhibition in } \\
\text { a dose-dependent manner. } \\
\text { Immune control of chlamydial } \\
\text { infections may trigger NO } \\
\text { production. }\end{array}$ & [83] \\
\hline $\begin{array}{l}\text { Enterococcus } \\
\text { faecium }\end{array}$ & C. suis & $\begin{array}{l}\text { In vivo } \\
\text { Prophylaxis: from } 24 \text { days } \\
\text { after mating, administered } \\
\text { daily for } 13 \text { weeks for } \\
\text { sows \& } 8 \text { weeks for } \\
\text { piglets. (pigs) }\end{array}$ & $\begin{array}{l}\text { Swine consuming E. faecium for } \\
13 \text { weeks before and } 8 \text { weeks after } \\
\text { giving birth, reduced the rate of } \\
\text { infected piglets from } 85 \% \text { to } 60 \% \text {. } \\
\text { The appearance of infection was } \\
\text { also delayed. }\end{array}$ & [85] \\
\hline $\begin{array}{l}\text { L. brevis, } \\
\text { L. salivarius }\end{array}$ & $\begin{array}{l}\text { C. trachomatis } \\
\text { (L2) }\end{array}$ & $\begin{array}{l}\text { In vitro } \\
\text { Pre-treatment: incubated } \\
\text { with EBs for } 1 \mathrm{~h} \text { prior to } \\
\text { inoculation. } \\
\text { Co-inoculation: inoculated } \\
\text { cells simultaneously with } \\
\text { EBs for } 1 \mathrm{~h} \text {. } \\
\text { Post-inoculation: } \\
\text { administered at } 0 \mathrm{~h} \text { p.i. }\end{array}$ & $\begin{array}{l}\text { L. brevis was significantly more } \\
\text { effective than L. salivarius. } \\
\text { Both lactobacilli had an adverse effect } \\
\text { on chlamydial EBs, on chlamydial } \\
\text { adsorption to epithelial cells, and on } \\
\text { intracellular phases of } \\
\text { chlamydial replication. } \\
\text { L. brevis inhibited HSV-2-induced } \\
\text { C. trachomatis persistence. }\end{array}$ & [86] \\
\hline $\begin{array}{l}\text { L. crispatus } \\
(\times 2), \\
\text { L. gasseri, } \\
\text { L. jensenii }\end{array}$ & $\begin{array}{l}\text { C. trachomatis } \\
\text { (D), } \\
\text { (L2) }\end{array}$ & $\begin{array}{l}\text { In vitro } \\
\text { Pre-treatment: incubated } \\
\text { with EBs for } 1 \mathrm{~h} \text { prior } \\
\text { to inoculation. }\end{array}$ & $\begin{array}{l}\text { Lactobacillus-conditioned media from } \\
\text { each of the lactobacillus strains } \\
\text { exhibited similar inhibitory activity. } \\
\text { Acidic } \mathrm{pH} \text { due to lactic acid } \\
\text { production was attributed to } \\
\text { chlamydial inhibition. } \\
\text { Levels of } \mathrm{H}_{2} \mathrm{O}_{2} \text { present did not } \\
\text { produce chlamydial inhibition. }\end{array}$ & [87] \\
\hline L.crispatus & $\begin{array}{l}\text { C. trachomatis } \\
\text { (D) }\end{array}$ & $\begin{array}{l}\text { In vitro } \\
\text { Pre-inoculation: } \\
\text { incubated with cells for } 6 \mathrm{~h} \\
\text { prior to inoculation. }\end{array}$ & $\begin{array}{l}\text { L. crispatus inhibits the adhesion of } \\
\text { chlamydial cells to human epithelial } \\
\text { cells or macrophages, and inhibited } \\
\text { C. trachomatis infectivity. } \\
\text { Modulation of inflammatory } \\
\text { cytokines, IL- } 6 \text {, IL- } 8 \text {, and TNF- } \alpha \text {, and } \\
\text { anti-inflammatory cytokine, IL-10, } \\
\text { was observed. }\end{array}$ & [88] \\
\hline $\begin{array}{l}\text { Bacteria } \\
\text { L. crispatus } \\
(\times 8) \text {, } \\
\text { L. gasseri }(\times 6), \\
\text { L. vaginalis }(\times 3) \\
\text { Cellular } \\
\text { Metabolite } \\
\text { Lactic acid }\end{array}$ & $\begin{array}{l}\text { C. trachomatis } \\
\text { (D) }\end{array}$ & $\begin{array}{l}\text { In vitro } \\
\text { Pre-treatment: } \\
\text { incubated with EBs for } 7, \\
\text { 15, or } 60 \text { min prior to } \\
\text { inoculation. }\end{array}$ & $\begin{array}{l}\text { L. crispatus exhibited highest efficacy } \\
\text { although all lactobacilli exerted } \\
\text { a strong inhibitory effect. } \\
\text { Activity corresponds to increased } \\
\text { cellular metabolites and a resulting } \\
\text { lower pH. } \\
\text { Both lactic acid and acidic conditions } \\
\text { were necessary for inhibition. } \\
\text { Lactobacilli supernatants exhibited } \\
\text { greater inhibition than only } \\
\text { lactic acid. }\end{array}$ & [89] \\
\hline
\end{tabular}

\subsection{Polyherbal Formulations}

There exist several polyherbal formulations which provide compelling insight into the antichlamydial potential of natural products. Table 6 summarizes the results of investigations into the effects of polyherbal formulations in the treatment of chlamydial infections. Praneem is a polyherbal formulation developed by Talwar et al. in the 1990s and has gone through Phase II trials for use as a spermicide and broad-spectrum antimicrobial. These studies have shown that Praneem is effective against $C$. trachomatis. The formulation has been used in the development of three antimicrobial products: a cream, a pessary, and an insertable tablet. Praneem contains saponins extracted from the pericarp of reetha tree (Sapindus mukorossi) fruit, quinine hydrochloride, and a purified extract from neem (Azadirachta indica) seeds as the main active ingredient. Toxicity studies indicate a lack of side 
effects, such as skin irritation or sensitization. Neem seeds contain water-soluble polysaccharides that stimulate antitumor and antiviral cytokines, including $\gamma$-interferon, which cause cell-mediated immune responses [90]. Praneem is more useful for preventing the spread of infections and treating some symptoms, as the polyherbal cream treats local, not systemic, infections [91,92]. In Phase I clinical trials, daily topical application of $5 \mathrm{~mL}$ of the cream for eight days, resulted in C. trachomatis being cleared from the cervicovaginal region of every subject studied [90]. The polyherbal formulation, $\mathrm{CH}-005$, was also developed by Talwar et al. and studied alongside Praneem for its efficacy as a broad-spectrum antimicrobial against reproductive tract infections and sexually transmitted pathogens. The polyherbal formulation, CH-005, comprises purified saponins from S. mukorossi, Mentha citrata oil, and a natural polycationic polymer. In a mouse model study, topical application of either $\mathrm{CH}-005$ or Praneem was effective in blocking the vaginal transmission of $\mathrm{C}$. trachomatis, with $\mathrm{CH}-005$ resulting in a $4.17 \%$ transmission rate and Praneem resulting in a 13.9\% transmission rate (Figure 6A). It is claimed that additional studies, at John Hopkins University, to inhibit the vaginal transmission of $C$. trachomatis with a range of potential microbicides resulted in polyherbal formulations providing the best results [91].
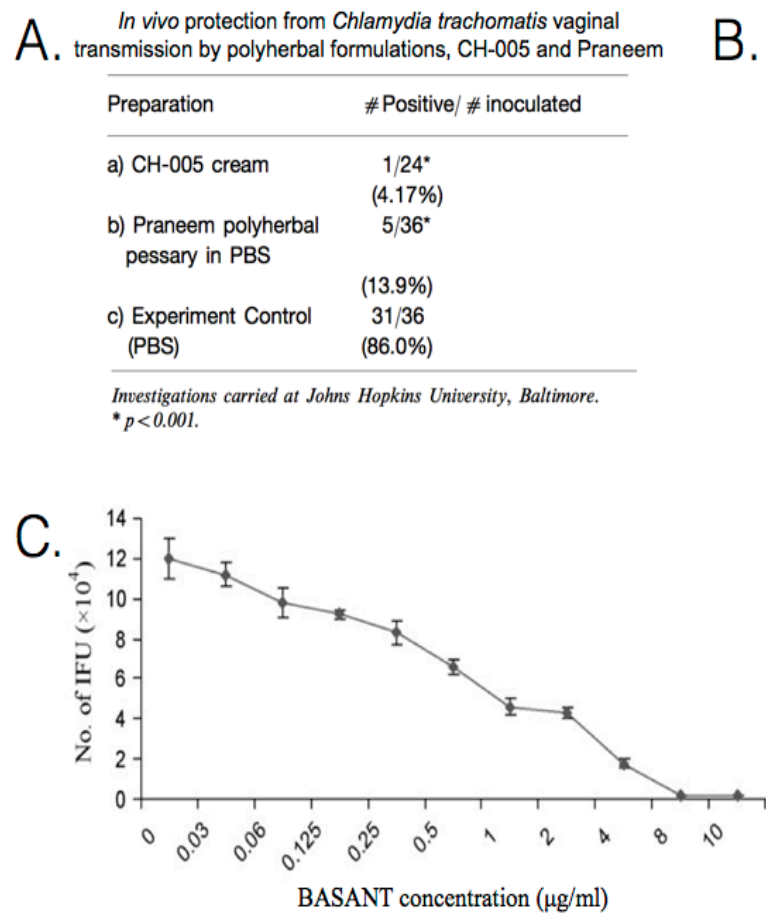

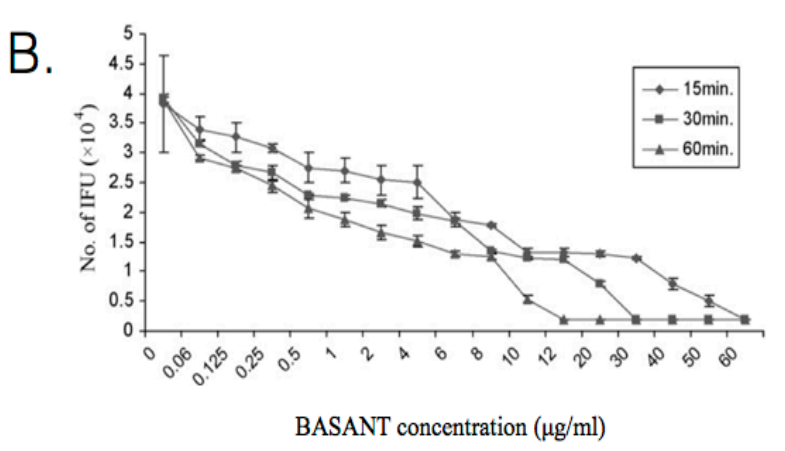

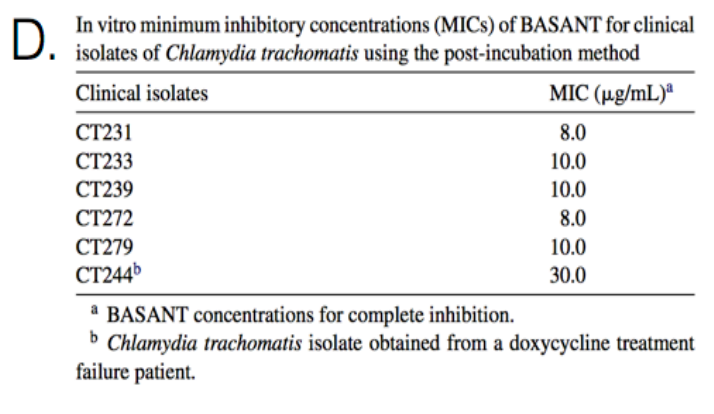

Figure 6. Efficacy of polyherbal formulations CH-005, Praneem, and BASANT. (A) In vivo protection from Chlamydia trachomatis vaginal transmission by polyherbal formulations $\mathrm{CH}-005$ and Praneem; (B) Inhibitory effect of BASANT on C. trachomatis from pre-infection incubation. The number of inclusion-forming units (IFUs) decreases with incubation time and BASANT concentration; (C) Inhibitory effect of BASANT on C. trachomatis serovar D from post-infection incubation. The minimum inhibitory concentration (MIC) was determined to be $8 \mu \mathrm{g} / \mathrm{mL}$ BASANT; (D) in vitro MICs of BASANT for clinical isolates of $C$. trachomatis from post-incubation incubation. Standard deviations from triplicate tests are indicated by error bars. Part A is adapted with permission from [91]. Copyright 2000 American Journal of Reproductive Immunology. Parts (B-D) are adapted with permission from [93]. Copyright 2008 International Society of Chemotherapy.

BASANT is a polyherbal formulation developed by Bhengraj et al. that can be used as a cream or tablet as a vaginal microbicide, and the cream has gone through Phase II clinical trials in India. The incubation of cells with BASANT, both before inoculation with doxycycline-resistant $C$. trachomatis and after, showed antimicrobial activity against sexually transmitted serovars of $C$. trachomatis. BASANT is comprised of Aloe vera, curcumin, saponins from S. mukerossi, and amla (Phyllanthus emblica). 
It is proposed that the components have a synergistic effect that enhances the properties of each ingredient and broadens the spectrum of treatable infections. A. vera has wound healing properties and has been shown to inhibit HIV and HPV. Curcumin has antiseptic, anti-inflammatory, and antitumor properties. Amla has antioxidant, anti-inflammatory, and antimutagenic properties. In pre-infection in vitro studies, HeLa cells were infected with C. trachomatis serovar D and exposed to BASANT solutions of varying concentration. Based on pre-incubation exposure, complete inhibition was achieved with $15 \mathrm{~min}$ incubation at a concentration of $65 \mu \mathrm{g} / \mathrm{mL}, 30 \mathrm{~min}$ incubation at $35 \mu \mathrm{g} / \mathrm{mL}$, and $60 \mathrm{~min}$ incubation at $15 \mu \mathrm{g} / \mathrm{mL}$ (Figure 6B). Based on in vitro post-incubation exposure, the minimum inhibitory concentration (MIC) was determined to be $\sim 9 \mu \mathrm{g} / \mathrm{mL}$ (Figure 6C,D). With C. trachomatis isolates from a doxycycline treatment failure patient, the MIC was $30 \mu \mathrm{g} / \mathrm{mL}$. There are no known side effects of BASANT, which is equally effective as a cream or tablet $[93,94]$.

Table 6. Past studies exploring antichlamydial properties of polyherbal formulations.

\begin{tabular}{|c|c|c|c|c|}
\hline $\begin{array}{c}\text { Antimicrobial } \\
\text { Agent }\end{array}$ & $\begin{array}{c}\text { Chlamydial } \\
\text { Species }\end{array}$ & Study Design & Effects & References \\
\hline $\begin{array}{l}\text { Praneem: } \\
\text { S. mukerossi } \\
\text { saponins, } \\
\text { A. indica seed } \\
\text { extract, } \\
\text { Quinine } \\
\text { hydrochloride }\end{array}$ & $\begin{array}{l}\text { C. trachomatis } \\
\text { (D) }\end{array}$ & $\begin{array}{l}\text { In vivo } \\
\text { Pre-inoculation: one dose } \\
\text { administered prior to } \\
\text { inoculation. (mice) } \\
\text { Clinical treatment: } \\
\text { administered daily for } \\
7 \text { days. (human) }\end{array}$ & $\begin{array}{l}\text { Application of } 5 \mathrm{~mL} \text { of cream for } \\
8 \text { days, resulted in C. trachomatis } \\
\text { being cleared from the } \\
\text { cervicovaginal region of patients. } \\
\text { Topical application is effective in } \\
\text { blocking chlamydial vaginal } \\
\text { transmission, with a transmission } \\
\text { rate of only } 14 \% \text {. } \\
\text { Toxicity studies indicate a lack of } \\
\text { side effects, such as skin irritation } \\
\text { or sensitization. }\end{array}$ & [90-92] \\
\hline $\begin{array}{l}\text { CH-005: } \\
\text { S. mukerossi } \\
\text { saponins, } \\
\text { M. citrata oil, } \\
\text { Natural } \\
\text { polycationic } \\
\text { polymer }\end{array}$ & $\begin{array}{l}\text { C. trachomatis } \\
\text { (D) }\end{array}$ & $\begin{array}{l}\text { In vivo } \\
\text { Pre-inoculation: one dose } \\
\text { administered prior to } \\
\text { inoculation. (mice) }\end{array}$ & $\begin{array}{l}\text { Topical application is effective in } \\
\text { blocking chlamydial vaginal } \\
\text { transmission with a transmission } \\
\text { rate of only } \sim 4 \% \text {. }\end{array}$ & [91] \\
\hline $\begin{array}{l}\text { BASANT: } \\
\text { S. mukerossi } \\
\text { saponins, } \\
\text { A. vera, } \\
\text { P. emblica, } \\
\text { curcumin }\end{array}$ & $\begin{array}{l}\text { C. trachomatis } \\
\text { (D) }\end{array}$ & $\begin{array}{l}\text { In vitro } \\
\text { Pre-treatment: incubated } \\
\text { with EBs for } 15,30 \text {, or } \\
60 \text { min prior to inoculation. } \\
\text { Post-inoculation: } \\
\text { administered at } 2 \text { h p.i. }\end{array}$ & $\begin{array}{l}\text { In vitro pre-incubation exposure, } \\
100 \% \text { inhibition was achieved in } \\
15 \mathrm{~min} \text { at } 65 \mu \mathrm{g} / \mathrm{mL}, 30 \mathrm{~min} \text { at } \\
35 \mu \mathrm{g} / \mathrm{mL} \text {, and } 60 \mathrm{~min} \text { at } \\
15 \mu \mathrm{g} / \mathrm{mL} \text {. } \\
\text { In vitro post-incubation exposure, } \\
\text { the } \mathrm{MIC} \text { was determined to be } \\
\sim 9 \mu \mathrm{g} / \mathrm{mL} \text {. } \\
\text { There are no known side effects of } \\
\text { BASANT, which is equally } \\
\text { effective as a cream or tablet. }\end{array}$ & {$[93,94]$} \\
\hline
\end{tabular}

\section{Conclusions}

Through the utilization of various compound classes identified within these studies it seems likely that ongoing research in this field could lead to the development of effective antichlamydial products and treatment strategies. A wide range of natural compounds have been studied which exhibit varying degrees of antichlamydial activity. Polyphenolic compounds have been explored from commonly available sources, such as tea, mint, bark, clover, and traditional herbal therapeutics. Lipidic compounds have been explored in the form of purified fatty acids, breast milk lipids, and tree heartwood terpenoids. Proteinaceous compounds have been explored in the form of aqueous protein extracts from desert truffles, various peptides extracted from humans, pigs, sheep, cattle, moths, bee venom, and frog skin, and iron-binding glyco-proteins from humans, pigs, and chickens. Cellular metabolites \& probiotics have been explored in the form of nitric oxide (NO), lactic acid, E. faecium, and six species of lactobacilli. Perhaps most importantly, three polyherbal formulations, utilizing various extracts from reetha tree fruit, cinchona bark, neem seeds, lemon mint, Aloe vera, 
turmeric, and Indian gooseberry, have demonstrated significant antichlamydial activity and highlight the potential for utilizing existing natural products to develop effective antichlamydial therapeutics.

To ensure long-term effective management of all Chlamydiaceae-related infections we should both prepare for the further development of clinical antibiotic resistance, as well as develop new options for providing better livestock management with the aim of preventing the development of antibiotic resistance. The exploration for new naturally derived or synthetic compounds is important, however, many modern antibiotics are already derivatives of natural products [95], and the further development of antibiotic resistance is always a possibility [96]. Although working with natural products is often challenging due to the biochemical complexity typically present, it is likely that this biochemical complexity offers a more reliable solution to infectious disease management.

Antibiotic resistance is the result of the natural evolutionary struggle between pathogens and hosts, and is often due to mutations in pathogenic bacteria, which eventually result in evolutionary solutions to improve on compounds with single mechanisms of action [96]. A standard approach to treating antibiotic resistant pathogens is multidrug therapy wherein two or more antibiotics are administered in an attempt to circumvent a pathogen's ability to quickly adapt to a single stressor [97]. A multi-drug treatment may be more effective in treating chlamydial infections than a single drug approach, and it is important to devote greater effort into exploring synergistic antichlamydial compound combinations [98], as well as pursuing greater standardization of herbal therapeutics. Growing application of nanomedicine formulations for natural products in the context of antimicrobial applications of various kinds also deserves attention and could lead to improved formulations [99]. Overall, natural products show significant potential in treating chlamydial infections and the development of these products into novel drugs may help in the global management of Chlamydiae-related infections.

Acknowledgments: The authors wish to acknowledge support from the National Research Foundation of Singapore, National Medical Research Council of Singapore, and Nanyang Technological University. This work was funded by the NRF Research Fellowship grant NRF-NRFF2011-01 (to N.-J.C) and the National Medical Research Council grant NMRC/CBRG/0005/2012 (to N.-J.C). M.G.P is a recipient of a SINGA Scholarship.

Author Contributions: M.A.B, M.G.P, and N.-J.C initiated and designed the study. M.A.B, M.G.P, and S.-W.T collected the literature and prepared the manuscript. N.-J.C provided critical comments for revisions of the manuscript. All authors read and approved the final version of the manuscript.

Conflicts of Interest: The authors declare no conflict of interest.

\section{References}

1. Taylor-Brown, A.; Vaughan, L.; Greub, G.; Timms, P.; Polkinghorne, A. Twenty years of research into Chlamydia-like organisms: A revolution in our understanding of the biology and pathogenicity of members of the phylum Chlamydiae. Pathog. Dis. 2015, 73, 1-15. [CrossRef] [PubMed]

2. Taylor, H.R.; Burton, M.J.; Haddad, D.; West, S.; Wright, H. Trachoma. Lancet 2014, 384, 2142-2152. [CrossRef]

3. Bébéar, C.; de Barbeyrac, B. Genital Chlamydia trachomatis infections. Clin. Microbiol. Infect. 2009, 15, 4-10. [CrossRef] [PubMed]

4. Grayston, J.T. Infections caused by Chlamydia pneumoniae strain twar. Clin. Infect. Dis. 1992, 15, 757-761. [CrossRef] [PubMed]

5. Kohlhoff, S.A.; Hammerschlag, M.R. Treatment of chlamydial infections: 2014 update. Expert Opin. Pharmacother. 2015, 16, 205-212. [CrossRef] [PubMed]

6. Walker, E.; Lee, E.J.; Timms, P.; Polkinghorne, A. Chlamydia pecorum infections in sheep and cattle: A common and under-recognised infectious disease with significant impact on animal health. Vet. J. 2015, 206, 252-260. [CrossRef] [PubMed]

7. Kong, F.; Tabrizi, S.; Law, M.; Vodstrcil, L.; Chen, M.; Fairley, C.; Guy, R.; Bradshaw, C.; Hocking, J. Azithromycin versus doxycycline for the treatment of genital Chlamydia infection-A meta-analysis of randomised controlled trials. Clin. Infect. Dis. 2014, 59, 193-205. [CrossRef] [PubMed] 
8. Kong, F.Y.S.; Tabrizi, S.N.; Fairley, C.K.; Vodstrcil, L.A.; Huston, W.M.; Chen, M.; Bradshaw, C.; Hocking, J.S. The efficacy of azithromycin and doxycycline for the treatment of rectal Chlamydia infection: A systematic review and meta-analysis. J. Antimicrob. Chemother. 2015, 70, 1290-1297. [CrossRef] [PubMed]

9. Rodolakis, A.; Mohamad, K.Y. Zoonotic potential of chlamydophila. Vet. Microbiol. 2010, 140, $382-391$. [CrossRef] [PubMed]

10. Rodolakis, A.; Laroucau, K. Chlamydiaceae and chlamydial infections in sheep or goats. Vet. Microbiol. 2015, 181, 107-118. [CrossRef] [PubMed]

11. Horner, P.J. Azithromycin antimicrobial resistance and genital Chlamydia trachomatis infection: Duration of therapy may be the key to improving efficacy. Sex. Transm. Infect. 2012, 88, 154-156. [CrossRef] [PubMed]

12. Hoffmann, K.; Schott, F.; Donati, M.; Di Francesco, A.; Hässig, M.; Wanninger, S.; Sidler, X.; Borel, N. Prevalence of chlamydial infections in fattening pigs and their influencing factors. PLoS ONE 2015, 10, e0143576. [CrossRef] [PubMed]

13. Sandoz, K.M.; Rockey, D.D. Antibiotic resistance in Chlamydiae. Future Microbiol. 2010, 5, 1427-1442. [CrossRef] [PubMed]

14. Hong, K.C.; Schachter, J.; Moncada, J.; Zhou, Z.; House, J.; Lietman, T.M. Lack of macrolide resistance in Chlamydia trachomatis after mass azithromycin distributions for trachoma. Emerg. Infect. Dis. 2009, 15, 1088-1090. [CrossRef] [PubMed]

15. West, S.; Moncada, J.; Munoz, B.; Mkocha, H.; Storey, P.; Hardick, J.; Gaydos, C.A.; Quinn, T.C.; Schachter, J. Is there evidence for resistance of ocular Chlamydia trachomatis to azithromycin after mass treatment for trachoma control? J. Infect. Dis. 2014, 210, 65-71. [CrossRef] [PubMed]

16. Vasilevsky, S.; Greub, G.; Nardelli-Haefliger, D.; Baud, D. Genital Chlamydia trachomatis: Understanding the roles of innate and adaptive immunity in vaccine research. Clin. Microbiol. Rev. 2014, 27, 346-370. [CrossRef] [PubMed]

17. Harkinezhad, T.; Geens, T.; Vanrompay, D. Chlamydophila psittaci infections in birds: A review with emphasis on zoonotic consequences. Vet. Microbiol. 2009, 135, 68-77. [CrossRef] [PubMed]

18. Saikku, P.; Wang, S.; Kleemola, M.; Brander, E.; Rusanen, E.; Grayston, J. An epidemic of mild pneumonia due to an unusual strain of Chlamydia psittaci. J. Infect. Dis. 1985, 151, 832-839. [CrossRef] [PubMed]

19. Grayston, J.T.; Kuo, C.-C.; Wang, S.-P.; Altman, J. A new Chlamydia psittaci strain, twar, isolated in acute respiratory tract infections. N. Engl. J. Med. 1986, 315, 161-168. [CrossRef] [PubMed]

20. Cox, R.L.; Kuo, C.-C.; Grayston, J.T.; Campbell, L.A. Deoxyribonucleic acid relatedness of Chlamydia sp. Strain twar to Chlamydia trachomatis and Chlamydia psittaci. Int. J. Syst. Evol. Microbiol. 1988, 38, 265-268. [CrossRef]

21. Grayston, J.; Wang, S.; Kuo, C. Current knowledge of Chlamydia twar, an important cause of pneumonia and other acute respiratory diseases. In Perspectives in Antiinfective Therapy; Springer: Berlin, Germany, 1989; pp. 339-359.

22. Grayston, J.T.; Kuo, C.-C.; Campbell, L.A.; Wang, S.-P. Chlamydia pneumoniae sp. nov. for Chlamydia sp. Strain twar. Int. J. Syst. Evol. Microbiol. 1989, 39, 88-90. [CrossRef]

23. Fukushi, H.; Hirai, K. Genetic diversity of avian and mammalian Chlamydia psittaci strains and relation to host origin. J. Bacteriol. 1989, 171, 2850-2855. [PubMed]

24. Fukushi, H.; Hirai, K. Proposal of Chlamydia pecorum sp. nov. for Chlamydia strains derived from ruminants. Int. J. Syst. Evol. Microbiol. 1992, 42, 306-308.

25. Everett, K.D.; Andersen, A.A. Identification of nine species of the Chlamydiaceae using PCR-RFLP. Int. J. Syst. Evol. Microbiol. 1999, 49, 803-813. [CrossRef] [PubMed]

26. Everett, K.D.; Bush, R.M.; Andersen, A.A. Emended description of the order Chlamydilaes, proposal of Parachlamydiaceae fam. nov. and Simkaniaceae fam. nov., each containing one monotypic genus, revised taxonomy of the family Chlamydiaceae, including a new genus and five new species, and standards for the identification of organisms. Int. J. Syst. Evol. Microbiol. 1999, 49, 415-440.

27. Everett, K.D. Chlamydia and Chlamydiales: More than meets the eye. Vet. Microbiol. 2000, 75, 109-126. [CrossRef]

28. Sachse, K.; Laroucau, K.; Riege, K.; Wehner, S.; Dilcher, M.; Creasy, H.H.; Weidmann, M.; Myers, G.; Vorimore, F.; Vicari, N. Evidence for the existence of two new members of the family Chlamydiaceae and proposal of Chlamydia avium sp. nov. and Chlachlamydia gallinacea sp. nov. Syst. Appl. Microbiol. 2014, 37, 79-88. [CrossRef] [PubMed] 
29. Elwell, C.; Mirrashidi, K.; Engel, J. Chlamydia cell biology and pathogenesis. Nat. Rev. Microbiol. 2016, 14, 385-400. [CrossRef] [PubMed]

30. Beale, A.S.; Upshon, P.A. Characteristics of murine model of genital infection with Chlamydia trachomatis and effects of therapy with tetracyclines, amoxicillin-clavulanic acid, or azithromycin. Antimicrob. Agents Chemother. 1994, 38, 1937-1943. [CrossRef] [PubMed]

31. Beeckman, D.S.A.; Vanrompay, D. Zoonotic chlamydophila psittaci infections from a clinical perspective. Clin. Microbiol. Infect. 2009, 15, 11-17. [CrossRef] [PubMed]

32. Reinhold, P.; Sachse, K.; Kaltenboeck, B. Chlamydiaceae in cattle: Commensals, trigger organisms, or pathogens? Vet. J. 2011, 189, 257-267. [CrossRef] [PubMed]

33. Longbottom, D.; Coulter, L. Animal Chlamydioses and zoonotic implications. J. Comp. Pathol. 2003, 128, 217-244. [CrossRef] [PubMed]

34. Polkinghorne, A.; Hanger, J.; Timms, P. Recent advances in understanding the biology, epidemiology and control of chlamydial infections in koalas. Vet. Microbiol. 2013, 165, 214-223. [CrossRef] [PubMed]

35. Black, L.; Higgins, D.; Govendir, M. In vitro activity of chloramphenicol, florfenicol and enrofloxacin against Chlamydia pecorum isolated from koalas (Phascolarctos cinereus). Aust. Vet. J. 2015, 93, 420-423. [CrossRef] [PubMed]

36. Sykes, J.E. Feline chlamydiosis. Clin. Tech. Small Anim. Pract. 2005, 20, 129-134. [CrossRef] [PubMed]

37. Binet, R.; Bowlin, A.K.; Maurelli, A.T.; Rank, R.G. Impact of azithromycin resistance mutations on the virulence and fitness of Chlamydia caviae in Guinea pigs. Antimicrob. Agents Chemother. 2010, 54, 1094-1101. [CrossRef] [PubMed]

38. Borel, N.; Leonard, C.; Slade, J.; Schoborg, R.V. Chlamydial antibiotic resistance and treatment failure in veterinary and human medicine. Curr. Clin. Microbiol. Rep. 2016, 3, 10-18. [CrossRef] [PubMed]

39. Yeruva, L.; Spencer, N.; Bowlin, A.K.; Wang, Y.; Rank, R.G. Chlamydial infection of the gastrointestinal tract: A reservoir for persistent infection. Pathog. Dis. 2013, 68, 88-95. [CrossRef] [PubMed]

40. Jantan, I.; Bukhari, S.N.A.; Mohamed, M.A.S.; Wai, L.K.; Mesaik, M.A. The evolving role of natural products from the tropical rainforests as a replenishable source of new drug leads. In Drug Discovery and Development_From Molecules to Medicine; Omboon, V., Suleiman, O., Eds.; InTech: Rijeka, Croatia, 2015.

41. Potroz, M.G.; Cho, N.-J. Natural products for the treatment of trachoma and Chlamydia trachomatis. Molecules 2015, 20, 4180-4203. [CrossRef] [PubMed]

42. Daglia, M. Polyphenols as antimicrobial agents. Curr. Opin. Biotechnol. 2012, 23, 174-181. [CrossRef] [PubMed]

43. Alvesalo, J.; Vuorela, H.; Tammela, P.; Leinonen, M.; Saikku, P.; Vuorela, P. Inhibitory effect of dietary phenolic compounds on Chlamydia pneumoniae in cell cultures. Biochem. Pharmacol. 2006, 71, 735-741. [CrossRef] [PubMed]

44. Sajilata, M.; Bajaj, P.R.; Singhal, R. Tea polyphenols as nutraceuticals. Compr. Rev. Food Sci. Food Saf. 2008, 7, 229-254. [CrossRef]

45. Ikigai, H.; Nakae, T.; Hara, Y.; Shimamura, T. Bactericidal catechins damage the lipid bilayer. Biochim. Biophys. Acta Biomembr. 1993, 1147, 132-136. [CrossRef]

46. Pandey, A.; Kumar, S. Perspective on plant products as antimicrobial agents: A review. Pharmacologia 2013, 4, 469-480. [CrossRef]

47. Yamazaki, T.; Inoue, M.; Sasaki, N.; Hagiwara, T.; Kishimoto, T.; Shiga, S.; Ogawa, M.; Hara, Y.; Matsumoto, T. In vitro inhibitory effects of tea polyphenols on the proliferation of Chlamydia trachomatis and Chlamydia pneumoniae. Jpn. J. Infect. Dis. 2003, 56, 143-145. [PubMed]

48. Yamazaki, T.; Kishimoto, T.; Shiga, S.; Sato, K.; Hagiwara, T.; Inoue, M.; Sasaki, N.; Ouchi, K.; Hara, Y. Biosynthesized tea polyphenols inactivate Chlamydia trachomatis in vitro. Antimicrob. Agents Chemother. 2005, 49, 2501-2503. [CrossRef] [PubMed]

49. Törmäkangas, L.; Vuorela, P.; Saario, E.; Leinonen, M.; Saikku, P.; Vuorela, H. In vivo treatment of acute Chlamydia pneumoniae infection with the flavonoids quercetin and luteolin and an alkyl gallate, octyl gallate, in a mouse model. Biochem. Pharmacol. 2005, 70, 1222-1230. [CrossRef] [PubMed]

50. Cheng, A.-C.; Huang, T.-C.; Lai, C.-S.; Pan, M.-H. Induction of apoptosis by luteolin through cleavage of BCL-2 family in human leukemia HL-60 cells. Eur. J. Pharmacol. 2005, 509, 1-10. [CrossRef] [PubMed]

51. Hao, H.; Aixia, Y.; Nancai, Y.; Wen, S. Baicalin suppresses expression of Chlamydia protease-like activity factor in HEP-2 cells infected by Chlamydia trachomatis. Fitoterapia 2009, 80, 448-452. [CrossRef] [PubMed] 
52. Salin, O.; Alakurtti, S.; Pohjala, L.; Siiskonen, A.; Maass, V.; Maass, M.; Yli-Kauhaluoma, J.; Vuorela, P. Inhibitory effect of the natural product betulin and its derivatives against the intracellular bacterium Chlamydia pneumoniae. Biochem. Pharmacol. 2010, 80, 1141-1151. [CrossRef] [PubMed]

53. Salin, O.; Tormakangas, L.; Leinonen, M.; Saario, E.; Hagstrom, M.; Ketola, R.A.; Saikku, P.; Vuorela, H.; Vuorela, P.M. Corn mint (Mentha arvensis) extract diminishes acute Chlamydia pneumoniae infection in vitro and in vivo. J. Agric. Food Chem. 2011, 59, 12836-12842. [CrossRef] [PubMed]

54. Kapp, K.; Hakala, E.; Orav, A.; Pohjala, L.; Vuorela, P.; Püssa, T.; Vuorela, H.; Raal, A. Commercial peppermint (Mentha $\times$ piperita L.) teas: Antichlamydial effect and polyphenolic composition. Food Res. Int. 2013, 53, 758-766. [CrossRef]

55. Hanski, L.; Genina, N.; Uvell, H.; Malinovskaja, K.; Gylfe, Å.; Laaksonen, T.; Kolakovic, R.; Mäkilä, E.; Salonen, J.; Hirvonen, J. Inhibitory activity of the isoflavone biochanin a on intracellular bacteria of genus Chlamydia and initial development of a buccal formulation. PLoS ONE 2014, 9, e115115. [CrossRef] [PubMed]

56. Salin, O.P.; Pohjala, L.L.; Saikku, P.; Vuorela, H.J.; Leinonen, M.; Vuorela, P.M. Effects of coadministration of natural polyphenols with doxycycline or calcium modulators on acute Chlamydia pneumoniae infection in vitro. J. Antibiot. 2011, 64, 747-752. [CrossRef] [PubMed]

57. Rizzo, A.; Romano Carratelli, C.; Losacco, A.; Iovene, M.R. Antimicrobial effect of natural polyphenols with or without antibiotics on Chlamydia pneumoniae infection in vitro. Microb. Drug Resist. 2014, 20, 1-10. [CrossRef] [PubMed]

58. Thormar, H. Antibacterial effects of lipids: Historical review (1881 to 1960). In Lipids and Essential Oils as Antimicrobial Agents; John Wiley \& Sons, Ltd.: Philadelphia, PA, USA, 2011; pp. 25-45.

59. Yoon, B.K.; Jackman, J.A.; Kim, M.C.; Cho, N.-J. Spectrum of membrane morphological responses to antibacterial fatty acids and related surfactants. Langmuir 2015, 31, 10223-10232. [CrossRef] [PubMed]

60. Bergsson, G.; Arnfinnsson, J.; Karlsson, S.M.; Steingrímsson, Ó.; Thormar, H. In vitro inactivation of Chlamydia trachomatis by fatty acids and monoglycerides. Antimicrob. Agents Chemother. 1998, 42, $2290-2294$. [PubMed]

61. Isaacs, C.E.; Kashyap, S.; Heird, W.C.; Thormar, H. Antiviral and antibacterial lipids in human milk and infant formula feeds. Arch. Dis. Child. 1990, 65, 861-864. [CrossRef] [PubMed]

62. Lampe, M.; Ballweber, L.; Isaacs, C.; Patton, D.; Stamm, W. Killing of Chlamydia trachomatis by novel antimicrobial lipids adapted from compounds in human breast milk. Antimicrob. Agents Chemother. 1998, 42, 1239-1244. [PubMed]

63. Skinner, M.; Kiselev, A.; Isaacs, C.; Mietzner, T.; Montelaro, R.; Lampe, M. Evaluation of WLBU2 peptide and 3-O-octyl-sn-glycerol lipid as active ingredients for a topical microbicide formulation targeting Chlamydia trachomatis. Antimicrob. Agents Chemother. 2010, 54, 627-636. [CrossRef] [PubMed]

64. Yamano, H.; Yamazaki, T.; Sato, K.; Shiga, S.; Hagiwara, T.; Ouchi, K.; Kishimoto, T. In vitro inhibitory effects of hinokitiol on proliferation of Chlamydia trachomatis. Antimicrob. Agents Chemother. 2005, 49, 2519-2521. [CrossRef] [PubMed]

65. Mandeel, Q.A.; Al-Laith, A.A.A. Ethnomycological aspects of the desert truffle among native bahraini and non-bahraini peoples of the kingdom of bahrain. J. Ethnopharmacol. 2007, 110, 118-129. [CrossRef] [PubMed]

66. Yasin, B.; Harwig, S.; Lehrer, R.I.; Wagar, E.A. Susceptibility of Chlamydia trachomatis to protegrins and defensins. Infect. Immun. 1996, 64, 709-713. [PubMed]

67. Lazarev, V.; Parfenova, T.; Gularyan, S.; Misyurina, O.Y.; Akopian, T.; Govorun, V. Induced expression of melittin, an antimicrobial peptide, inhibits infection by Chlamydia trachomatis and Mycoplasmahominis in a HeLa cell line. Int. J. Antimicrob. Agents 2002, 19, 133-137. [CrossRef]

68. Lazarev, V.; Shkarupeta, M.; Titova, G.; Kostrjukova, E.; Akopian, T.; Govorun, V. Effect of induced expression of an antimicrobial peptide melittin on Chlamydia trachomatis and Mycoplasma hominis infections in vivo. Biochem. Biophys. Res. Commun. 2005, 338, 946-950. [CrossRef] [PubMed]

69. Ballweber, L.; Jaynes, J.; Stamm, W.; Lampe, M. In vitro microbicidal activities of cecropin peptides D2A21 and D4E1 and gel formulations containing $0.1 \%$ to $2 \%$ D2A21 against Chlamydia trachomatis. Antimicrob. Agents Chemother. 2002, 46, 34-41. [CrossRef] [PubMed]

70. Bechinger, B. Structure and functions of channel-forming peptides: Magainins, cecropins, melittin and alamethicin. J. Membr. Biol. 1997, 156, 197-211. [CrossRef] 
71. Saberwal, G.; Nagaraj, R. Cell-lytic and antibacterial peptides that act by perturbing the barrier function of membranes: Facets of their conformational features, structure-function correlations and membrane-perturbing abilities. Biochim. Biophys. Acta Rev. Biomembr. 1994, 1197, 109-131. [CrossRef]

72. Boman, H.G. Gene-encoded peptide antibiotics and the concept of innate immunity: An update review. Scand. J. Immunol. 1998, 48, 15-25. [CrossRef] [PubMed]

73. Chong-Cerrillo, C.; Selsted, M.E.; Peterson, E.; De La Maza, L.M. Susceptibility of human and murine Chlamydia trachomatis serovars to granulocyte-and epithelium-derived antimicrobial peptides. J. Pept. Res. 2003, 61, 237-242. [CrossRef] [PubMed]

74. Yasin, B.; Pang, M.; Wagar, E. A cumulative experience examining the effect of natural and synthetic antimicrobial peptides vs. Chlamydia trachomatis. J. Pept. Res. 2004, 64, 65-71. [CrossRef] [PubMed]

75. Donati, M.; Di Leo, K.; Benincasa, M.; Cavrini, F.; Accardo, S.; Moroni, A.; Gennaro, R.; Cevenini, R. Activity of cathelicidin peptides against Chlamydia spp. Antimicrob. Agents Chemother. 2005, 49, 1201-1202. [CrossRef] [PubMed]

76. Donati, M.; Di Francesco, A.; Gennaro, R.; Benincasa, M.; Magnino, S.; Pignanelli, S.; Shurdhi, A.; Moroni, A.; Mazzoni, C.; Merialdi, G. Sensitivity of Chlamydia suis to cathelicidin peptides. Vet. Microbiol. 2007, 123, 269-273. [CrossRef] [PubMed]

77. Donati, M.; Di Francesco, A.; Gennaro, R.; Benincasa, M.; Di Paolo, M.; Shurdhi, A.; Ostanello, F.; Baldelli, R.; Cevenini, R. Increasing effect of a high dose of PG-1 peptide on the infectivity of chlamydophila abortus. FEMS Immunol. Med. Microbiol. 2010, 59, 221-222. [CrossRef] [PubMed]

78. Bergaoui, I.; Zaïri, A.; Gharsallah, H.; Aouni, M.; Hammami, A.; Hani, K.; Selmi, B. The in vitro evaluation of anti-chlamydial and cytotoxic properties of dermaseptin s4 and derivatives: Peptides from amphibian skin. Med. Chem. Res. 2013, 22, 6096-6104. [CrossRef]

79. García-Montoya, I.A.; Cendón, T.S.; Arévalo-Gallegos, S.; Rascón-Cruz, Q. Lactoferrin a multiple bioactive protein: An overview. Biochim. Biophys. Acta Gen. Subj. 2012, 1820, 226-236. [CrossRef] [PubMed]

80. Beeckman, D.S.A.; Van Droogenbroeck, C.M.; De Cock, B.J.; Van Oostveldt, P.; Vanrompay, D.C. Effect of ovotransferrin and lactoferrins on chlamydophila psittaci adhesion and invasion in HD11 chicken macrophages. Vet. Res. 2007, 38, 729-739. [CrossRef] [PubMed]

81. Van Droogenbroeck, C.; Beeckman, D.S.; Harkinezhad, T.; Cox, E.; Vanrompay, D. Evaluation of the prophylactic use of ovotransferrin against chlamydiosis in spf turkeys. Vet. Microbiol. 2008, 132, 372-378. [CrossRef] [PubMed]

82. Van Droogenbroeck, C.; Dossche, L.; Wauman, T.; Van Lent, S.; Phan, T.T.; Beeckman, D.S.; Vanrompay, D. Use of ovotransferrin as an antimicrobial in turkeys naturally infected with Chlamydia psittaci, Avian metapneumovirus and Ornithobacterium rhinotracheale. Vet. Microbiol. 2011, 153, 257-263. [CrossRef] [PubMed]

83. Carratelli, C.R.; Rizzo, A.; Paolillo, R.; Catania, M.R.; Catalanotti, P.; Rossano, F. Effect of nitric oxide on the growth of chlamydophila pneumoniae. Can. J. Microbiol. 2005, 51, 941-947. [CrossRef] [PubMed]

84. Tiso, M.; Schechter, A.N. Nitrate reduction to nitrite, nitric oxide and ammonia by gut bacteria under physiological conditions. PLOS ONE 2015, 10, e0119712.

85. Pollmann, M.; Nordhoff, M.; Pospischil, A.; Tedin, K.; Wieler, L. Effects of a probiotic strain of enterococcus faecium on the rate of natural Chlamydia infection in swine. Infect. Immun. 2005, 73, 4346-4353. [CrossRef] [PubMed]

86. Mastromarino, P.; Di Pietro, M.; Schiavoni, G.; Nardis, C.; Gentile, M.; Sessa, R. Effects of vaginal lactobacilli in Chlamydia trachomatis infection. Int. J. Med. Microbiol. 2014, 304, 654-661. [CrossRef] [PubMed]

87. Gong, Z.; Luna, Y.; Yu, P.; Fan, H. Lactobacilli inactivate Chlamydia trachomatis through lactic acid but not $\mathrm{H}_{2} \mathrm{O}_{2}$. PLoS ONE 2014, 9, e107758. [CrossRef] [PubMed]

88. Rizzo, A.; Fiorentino, M.; Buommino, E.; Donnarumma, G.; Losacco, A.; Bevilacqua, N. Lactobacillus crispatus mediates anti-inflammatory cytokine interleukin-10 induction in response to Chlamydia trachomatis infection in vitro. Int. J. Med. Microbiol. 2015, 305, 815-827. [CrossRef] [PubMed]

89. Nardini, P.; Palomino, R.A.N.; Parolin, C.; Laghi, L.; Foschi, C.; Cevenini, R.; Vitali, B.; Marangoni, A. Lactobacillus crispatus inhibits the infectivity of Chlamydia trachomatis elementary bodies, in vitro study. Sci. Rep. 2016, 6, 29024. [CrossRef] [PubMed]

90. Talwar, G.; Garg, S.; Dhar, V.; Chabra, R.; Ganju, A.; Upadhyay, S. Praneem polyherbal cream and pessaries with dual properties of contraception and alleviation of genital infections. Curr. Sci. 1995, 68, 437-440. 
91. Talwar, G.; Raghuvanshi, P.; Mishra, R.; Banerjee, U.; Rattan, A.; Whaley, K.J.; Achilles, S.L.; Zeitlin, L.; Barré-Sinoussi, F.; David, A. Polyherbal formulations with wide spectrum antimicrobial activity against reproductive tract infections and sexually transmitted pathogens. Am. J. Reprod. Immunol. 2000, 43, 144-151. [CrossRef] [PubMed]

92. Talwar, G. A polyherbal formulation for a wide spectrum of reproductive tract and sexually transmitted infections. In Complementary and Alternative Approaches to Biomedicine; Springer: New York, NY, USA, 2004; pp. 111-119.

93. Bhengraj, A.; Dar, S.A.; Talwar, G.; Mittal, A. Potential of a novel polyherbal formulation basant for prevention of Chlamydia trachomatis infection. Int. J. Antimicrob. Agents 2008, 32, 84-88. [CrossRef] [PubMed]

94. Bhengraj, A.; Goyal, A.; Talwar, G.; Mittal, A. Assessment of antichlamydial effects of a novel polyherbal tablet basant. Sex. Transm. Infect. 2009, 85, 561-5621. [CrossRef] [PubMed]

95. Chait, R.; Vetsigian, K.; Kishony, R. What counters antibiotic resistance in nature? Nat. Chem. Biol. 2012, 8, 2-5. [CrossRef] [PubMed]

96. Davies, J.; Davies, D. Origins and evolution of antibiotic resistance. Microbiol. Mol. Biol. Rev. 2010, 74, 417-433. [CrossRef] [PubMed]

97. Keshavjee, S.; Farmer, P.E. Tuberculosis, drug resistance, and the history of modern medicine. N. Engl. J. Med. 2012, 367, 931-936. [CrossRef] [PubMed]

98. Wagner, H.; Ulrich-Merzenich, G. Synergy research: Approaching a new generation of phytopharmaceuticals. Phytomedicine 2009, 16, 97-110. [CrossRef] [PubMed]

99. Jackman, J.A.; Lee, J.; Cho, N.J. Nanomedicine for infectious disease applications: Innovation towards broad-spectrum treatment of viral infections. Small 2016, 12, 1133-1139. [CrossRef] [PubMed]

(C) 2016 by the authors; licensee MDPI, Basel, Switzerland. This article is an open access article distributed under the terms and conditions of the Creative Commons Attribution (CC-BY) license (http:/ / creativecommons.org/licenses/by/4.0/). 